\title{
2011 年東北地方太平洋沖地震による絶対歪みの解放 : 遠地実体波インバージョン解析と動的摩擦弱化
}

Absolute strain release in the 2011 Tohoku-oki Earthquake: Waveform inversion and dynamic fault weakening

\section{深畑幸俊* 八木勇治 ${ }^{* *}$ 三井雄太 ${ }^{* * *}$}

Yukitoshi Fukahata*, Yuji Yagi** and Yuta Mitsui ${ }^{* * *}$

2011 年 12 月 15 日受付.

2012 年 5 月 5 日受理.

京都大学防災研究所

Disaster Prevention Research Institute, Kyoto University, Gokasho, Uji, Kyoto 611-0011, Japan

** 筑波大学生命環境系

Faculty of Life and Environmental Sciences, University of Tsukuba, Japan

**** 北海道大学理学研究院

Department of Natural History Sciences, Hokkaido University, Japan

Corresponding author; Y. Fukahata, fukahata@rcep.dpri.kyoto-u.ac.jp

\begin{abstract}
The 2011 Tohoku-oki earthquake resulted in substantial slip relatively near the coast from Miyagi to Ibaraki prefectures as well as extremely large slip near the trench. The moment-rate function has a shoulder around $35 \mathrm{~s}$ and a large peak about $70 \mathrm{~s}$. The former corresponds to a significant moment release in the source area of the 1978 Miyagi-oki earthquake, and the latter was caused by extremely large slip near the trench. The main rupture process is characterized was by large maximum slip $(50 \mathrm{~m})$, long slip duration in the large slip area $(90 \mathrm{~s})$, and a relatively large stress drop in the up-dip source region (10 MPa). These characteristics mean that dislocation across the plate interface continued to release elastic stress and strain during the earthquake, which strongly suggests significant weakening of frictional strength due to thermal pressurization or other mechanisms on the fault plane. A drastic change in earthquake mechanisms from compression to extension above the large-slip area together with the occurrence of low-angle normal-fault aftershocks at approximately the depth of the plate interface also supports the idea that the earthquake did release roughly all of the accumulated strain on the plate interface owing to dynamic weakening of the fault. The stress accumulated on the plate interface before the earthquake is estimated to have been about $10 \mathrm{MPa}$ from the hypocenter to the trench. If dynamic weakening on a fault plane plays an essential role in large earthquakes, then the periodicity of large earthquakes is questioned, as fault weakening mechanisms are non-linear in nature. Pseudo-cyclical records of the occurrence of large interplate earthquakes can be understood by constant accumulation of elastic strain due to steady plate motion and accidental release of elastic strain due to dynamic fault weakening that strongly depends on the conditions immediately prior to the earthquake.
\end{abstract}

Keywords: 2011 Tohoku-oki earthquake, absolute strain, absolute stress, waveform inversion, thermal pressurization

\section{は じめに}

2011 年東北地方太平洋沖地震 (以下, 東北沖大地震と略 記)は，プレート境界に溜められていた歪み(より正確には剪 断弾性歪み)をほとんど全て解放してしまうという, 極めて 特異な地震だつたと考えられる. この点が, 物理的な側面か ら見た場合の, この地震の最も重要な特徵であろう. 歪夕が ほぼ全て解放されたがために, $50 \mathrm{~m}$ に達する大きな滑りも 生じたのである. なぜプレート境界に溜められていた歪夕が ほぼ全て解放されたと考えられるのか，本論文では遠地実体 波解析 (Yagi and Fukahata, 2011a) や地震のメカニズム解 の変化 (Asano et al., 2011) を基に論証する. 付随して，分 量としてはむしろやや長くなるが，遠地実体波解析から得ら
れた破壊過程の詳細について, 他の解析結果との比較や各種 観測データとの整合性を基に，その妥当性について議論す る. 地震の破壊過程を確定させることが，この地震を理解す る上での基盤となるからである.

もしも, 歪みが本当にほぼ全て解放されていたならば, 応 力降下量の解析などから, 大地震前の応力の絶対レベルを見 積もることが可能となる. つまり, 東北沖大地震は, 応力の 絶対レベルを比較的精度良く見積もる得難い機会を提供す る. 歪みをほぼ全て解放するには何らかのメカニズム, 例え ば摩擦発熱による間隙流体圧の上昇などの効果により断層面 上の摩擦強度が地震時に極端に低下することが必要である. そのような極端な摩擦強度低下メカニズムは, 強い非線形 性, 即ち鋭敏な初期值依存性を持つことが期待される. 今回 
の地震でそのような極端な摩擦強度の低下メカニズムが重要 な役割を果たしたということは，我々が漠然と抱いている巨 大地震の周期的発生という観念に重大な疑問を突き付ける.

\section{インバージョン解析手法}

東北沖大地震の破壊過程を調べるために遠地実体波のイン バージョン解析を行つた(Yagi and Fukahata, 2011a)。遠 地実体波はグローバルな観測網によって捉えられているの で，異なる地域で発生した大地震間の比較に適している．加 えて, 波形は震源領域全体の情報をほぼ等しく含むため震源 過程全体を議論するのに優れ，特に地表面で反射した波が比 較的に孤立して到達するため深さ方向の分解能が高いという 特長を持つ.

最近では, 大地震の発生後に複数の機関から震源過程モデ ルが発表されるなど, 震源過程の推定は定常業務のように成 りつつある. その一方, 同様のデー夕を使用しているにも拘 わらず，研究者によってしばしば結果が大きく異なること (例えば, Beresnev, 2003; Vallée and Bouchon, 2004)は, 既存の解析手法に重大な問題があることを示している. この 問題を解決するために, 我々はデータが持つ誤差に注目し て, 解析手法の改善を図ってきた (Fukahata and Wright, 2008; Yagi and Fukahata, 2008, 2011b).

一般に誤差は観測誤差とモデル誤差よりなる．モデル誤差 は，グリーン関数の誤差などモデルが不完全であるために生 じる誤差で，デー夕間に大きな相関を作り出すという特徵を 持つ. 従来の解析では，ほとんどの場合モデル誤差と観測䛊 差を区別することなく，誤差は無相関でガウス分布に従うと 仮定してきた. ランダムな観測誤差が十分に大きい場合に は，これは悪い仮定ではない。しかし現今，地震計の精度は 非常に高く, 観測誤差よりもモデル誤差がむしろ大きいと考 えられるため, 誤差を無相関のガウス分布と仮定することに は無理がある. また，モデル誤差としては，グリーン関数の 不確定性に由来するものが支配的であると考えられる(Yagi and Fukahata, 2008, 2011b). そこで，Yagi and Fukaha$\operatorname{ta}(2011 b)$ は, その効果を取り入れたインバージョン解析法 の定式化を行った. 一般に, 遠地地震波形デー夕（変位 $u(\mathbf{x}$, $t))$ は, グリーン関数 $G(\mathbf{x}, \xi, t)$ を介して断層面上の滑り速 度 $\dot{D}(\xi, t)$ と結び付けられるが，下記のようにグリーン関数 の誤差 $\delta G$ を明示的に取り入れたところがポイントである :

$$
u(\mathbf{x}, t)=\int_{\Sigma}(G(\mathbf{x}, \xi, t)-\delta G(\mathbf{x}, \xi, t)) * \dot{D}(\xi, t) d \xi+e_{o b s}
$$

観測誤差を表す $e_{o b s}$ とグリーン関数の誤差 $\delta G$ に由来する項 が，観測方程式の䛊差を構成する. *は時間に関するコンボ リューション(畳み込み積分)を表しており, 誤差 $\delta G$ が滑り 速度 $\dot{D}$ とコンボリューションされていることから, 誤差が デー夕間で強い相関 (共分散成分)を持つことが分かる. この 方法により, 例えば後続波に污染されがちな地震波の後ろの 方のデー夕の重みを引き下げるなどといつたことが自然にな されると同時に, 非負の拘束条件(仮定したすべり方向と逆 向きの滑りを許さない条件のこと)を課さなくとももつとも らしい滑り分布が得られるようになつた. 非負の条件を課さ
ないことにより，不適切な設定で解析したときにはおかしな 結果が得られることが期待されると同時に, 計算時間が劇的 に節約できるので解析の分解能を大きく上げることが可能と なつた.このグリーン関数の誤差を明示的に取り入れた最新 の手法を東北沖大地震の観測デー夕に適用したところが Yagi and Fukahata(2011a)の解析の特徵である.

世界の広帯域地震観測網から 51 点をデー夕の質や方位を 基準に選び，観測波形に $0.001-0.38 \mathrm{~Hz}$ のバンドパスフィ ルターをかけた. 地殼構造は Miura et al. (2005)に準拠し, グリーン関数は Kikuchi and Kanamori(1991)の方法によ り計算している. 震源位置は気象庁のものを参考に北緯 $38.103^{\circ}$, 東経 $142.860^{\circ}$, 深さ $22 \mathrm{~km}$ とし, 断層の走向を $200^{\circ}$ ，傾斜角を $12^{\circ}$ とした. 断層面は北北東方向に 500 $\mathrm{km}$, 東南東方向に $200 \mathrm{~km}$ の範囲を取り, 両方向に $20 \mathrm{~km}$ 間隔で一次のスプライン関数を基底関数として配置した. 時 間方向には, 各空間パッチ毎に 102 秒間をモデル空間とし て取り, 1.2 秒間隔で一次のスプライン関数を基底関数とし て配置した. 各空間パッチの時間基底関数の開始時刻を与え る仮想的な破壊伝播速度は $2.8 \mathrm{~km} / \mathrm{s}$ とした. また, 滑り分 布はなめらかであるという先験的拘束条件を使用し, その重 みを赤池のベイズ情報量規準 $(\mathrm{ABIC})$ を用いて定めている (Akaike, 1980; Yabuki and Matsu'ura, 1992). インバー ジョン解析の結果, 各基底関数の重ね合わせ係数が得られ, それらを足し合わせることにより, 滑り分布の時間発展が得 られる.

得られた総計の滑り量分布を地図上に描いたものを Fig. 1 に，滑りベクトルを重ねたものを Fig. 2a に示す. 比較のた めに, グリーン関数の誤差を取り入れないで解析した結果を Fig. $2 b$ に示す. Fig. $2 b$ の解析では, 統計的に最適とされ る $\mathrm{ABIC}$ 最小解を採用すると滑り分布が非常に激しく暴れ てしまうため, それよりもかなり強いスムージングをかけて いる. また, ほとんど全ての波形インバージョン解析と同様 に非負の条件(NNLS: non-negative least squares)を課し ており, 計算時間の制約から時間方向のモデル領域を 72 秒, 基底関数の間隔を 7.2 秒とした. Fig. $2 \mathrm{~b}$ では海溝沿いの大 きな滑りが南まで分布するほか, モデル領域の両下端に比較 的大きな滑りが求まっている. 次節でも触れるように他の波 形インバージョン解析でもしばしば類似の特徵が見られる が，それらはおそらく擬似的なものだろう．なぜなら，非負 の条件をもしも用いないと, 滑り分布は Fig. 2c のようにな る. 本来ある筈のグリーン関数の誤差を無視すると, このよ うに物理的におかしな解が得られるのである. そして, 非負 の条件を課すというのは, なぜ物理的におかしな解が得られ たのかその原因を究明する代わりに, 滑り分布が一見もっと もらしく見えるよう強引に操作していることに相当する. 負 の滑りが推定誤差範囲に入るようなものならば問題はないだ ろうが, Fig. 2c のように小さくはない場合にはモデルの設 定に何らかの看過できない欠陥があることを意味しており， 得られた滑り分布の信頼性は限定的であると考えざるを得な い. 


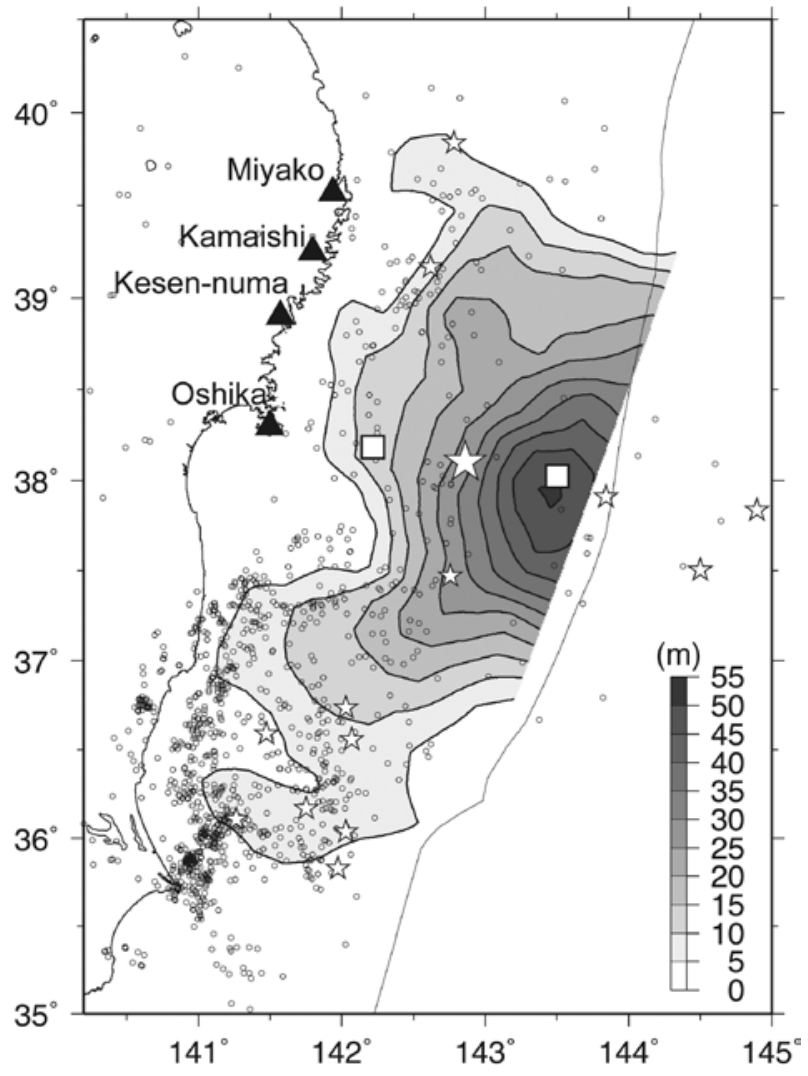

Fig. 1. Total slip distribution of the 2011 Tohoku-oki earthquake. The large star represents the epicenter determined by Japan Meteorological Agency (JMA). The first three-days aftershocks are also shown by small stars $(\geq M$ $6.5)$ and open circles $(<M 6.5)$. Triangles represent the locations of the GPS stations at Miyako, Kamaishi, Kesennuma and Oshika from north to south. The open squares and the hypocenter are used as source locations in culating the displacements shown in Fig. $9 \mathrm{~b}$.

\section{地震の滑り分布と破壊伝播過程}

\section{1. インバージョン解析結果}

Fig. 2a の滑りベクトル図から，東北沖大地震はほぼ純粋 な逆断層運動で, 滑りのピークは震源よりも海溝側にあり約 $50 \mathrm{~m}$ に達することが分かる. $5 \mathrm{~m}$ 以上の滑りが起こった領 域は, 長さ $440 \mathrm{~km}$, 幅 $180 \mathrm{~km}$ もの広がりを持つ. Fig. 3 にモーメント速度関数を示す． 35 秒付近で急激な上昇が一 服し, 次いで 70 秒付近に大きなピークを持つのが特徵であ る. 破壊の時間発展を Fig. 4 に, 各空間パッチのすべり速 度関数を Fig. 5 に示す.これらの図は滑り量および滑り速 度で表現されているため，モーメント解放量(または，モー メント解放レート)で見た場合には, 海溝寄りと震源以深を 比較する際に後者が 2 倍以上大きくなることに注意された い.なお，インバージョン解析では層構造の弾性体を仮定 し，ポアソン比は一律に 0.25 としている. 各深さの剛性率 の値は Fig. 5 右端に示した.

滑り分布から剛性率 $54 \mathrm{MPa}$ の一様な半無限弾性体を仮 定して計算した応力降下量を Fig. 6a に示す. 応力降下量の (a) New Formulation

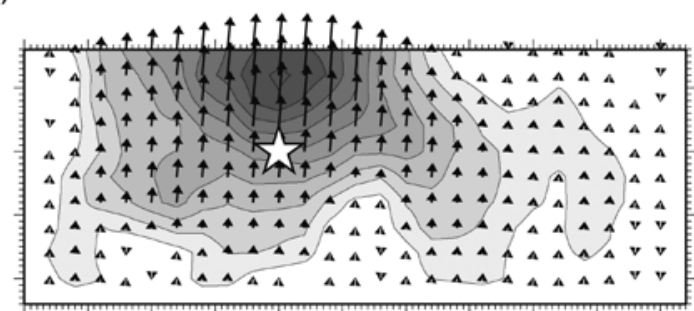

(b) Conventional Formulation with NNLS

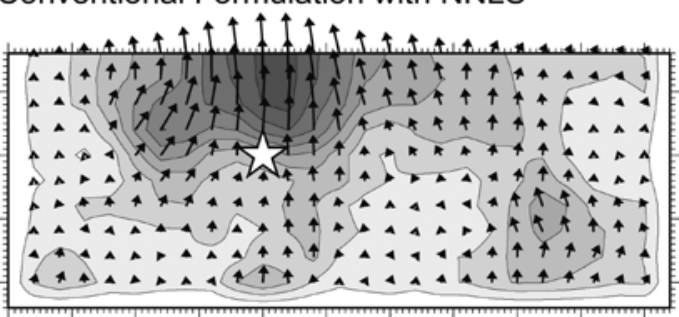

(c) Conventional Formulation without NNLS

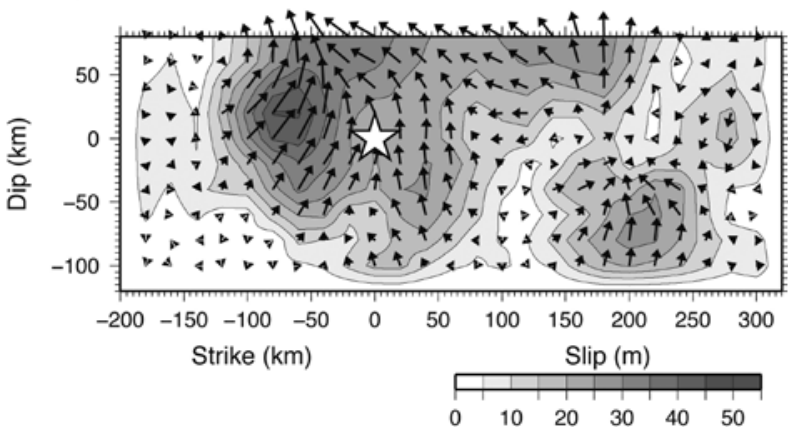

Fig. 2. Comparison between total slip distributions inverted with the new (a) and the conventional formulations with (b) and without (c) NNLS (non-negative least squares). The arrow shows the direction of slip, which can deviate by no more than $\pm 45^{\circ}$ from pure dip slip in (b) because of the non-negative condition. In the conventional formulation, we neglect the data covariance components originating from uncertainty of Green's function (Yagi and Fukahata, 2011b), and the number of model parameters is reduced by using longer basis functions (from $1.2 \mathrm{~s}$ to 7.2 s) for a shorter model space (from $102 \mathrm{~s}$ to $72 \mathrm{~s}$ ) due to restriction of computational time (see the text). The star represents the hypocenter.

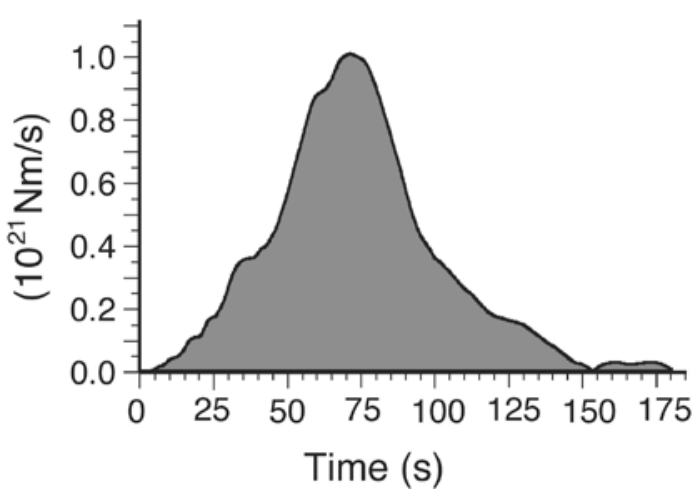

Fig. 3. Moment-rate function of the 2011 Tohoku-oki earthquake. 

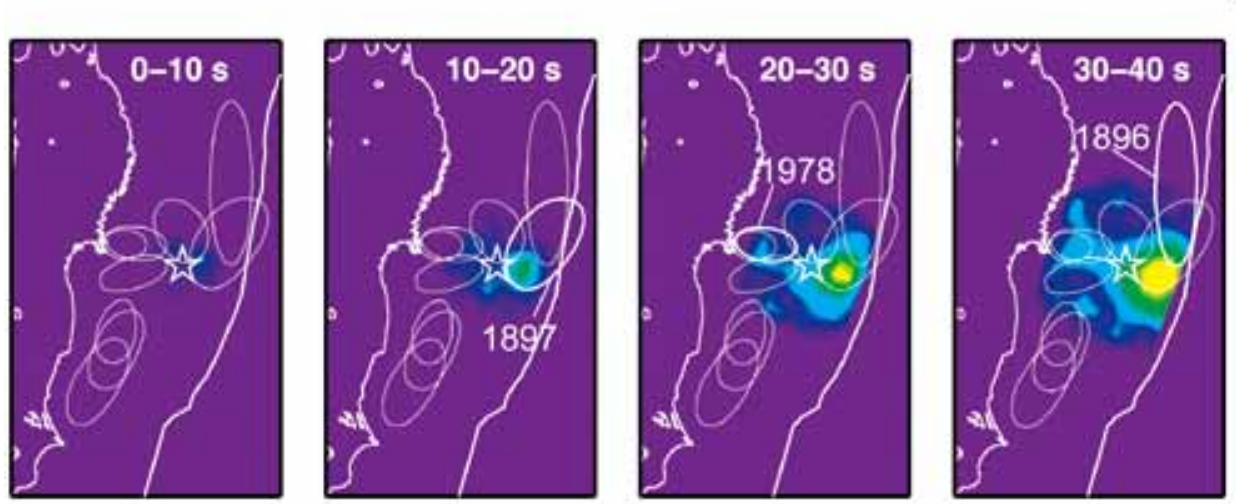

$140^{\circ} 142^{\circ} 144^{\circ}$
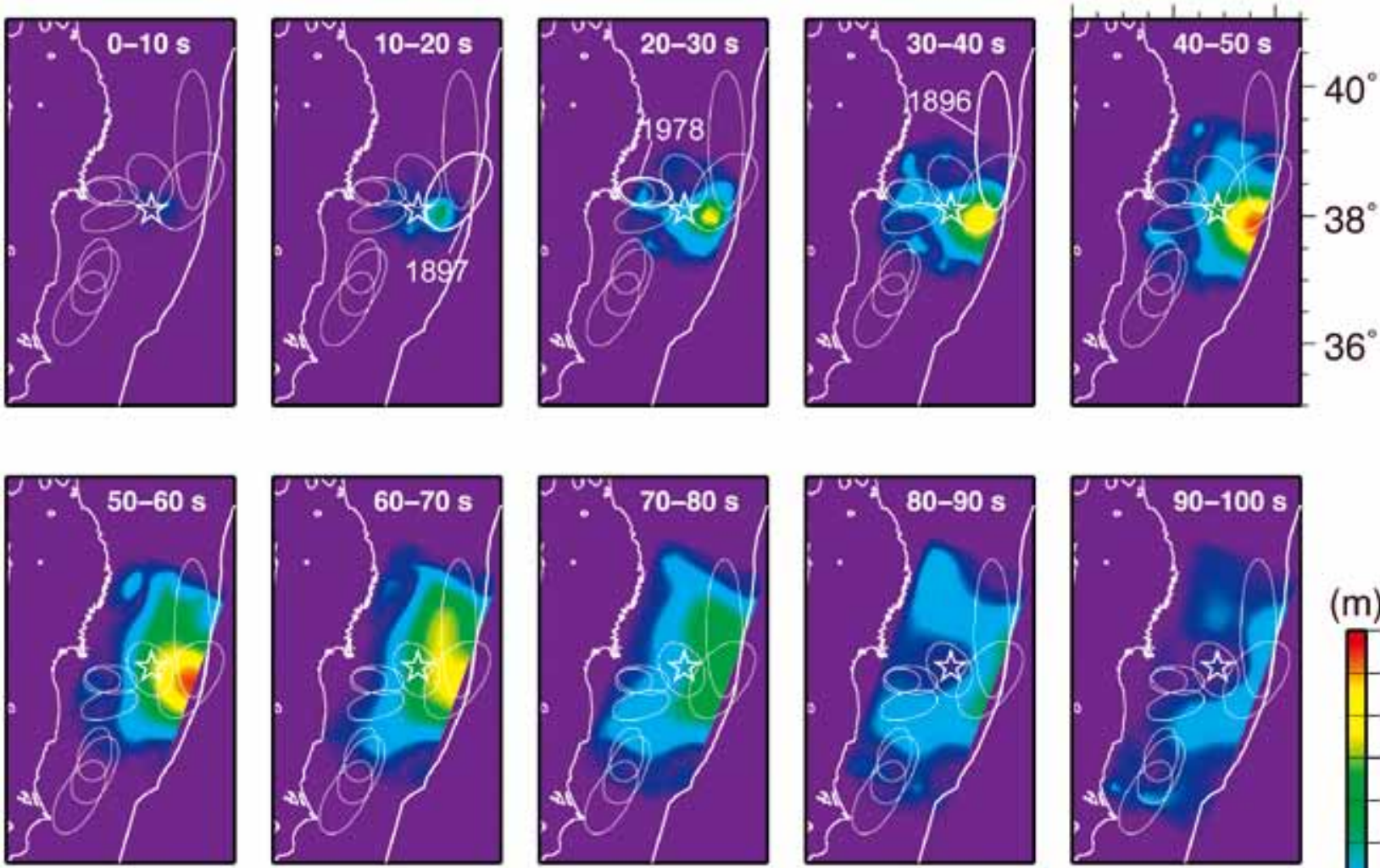

(m)
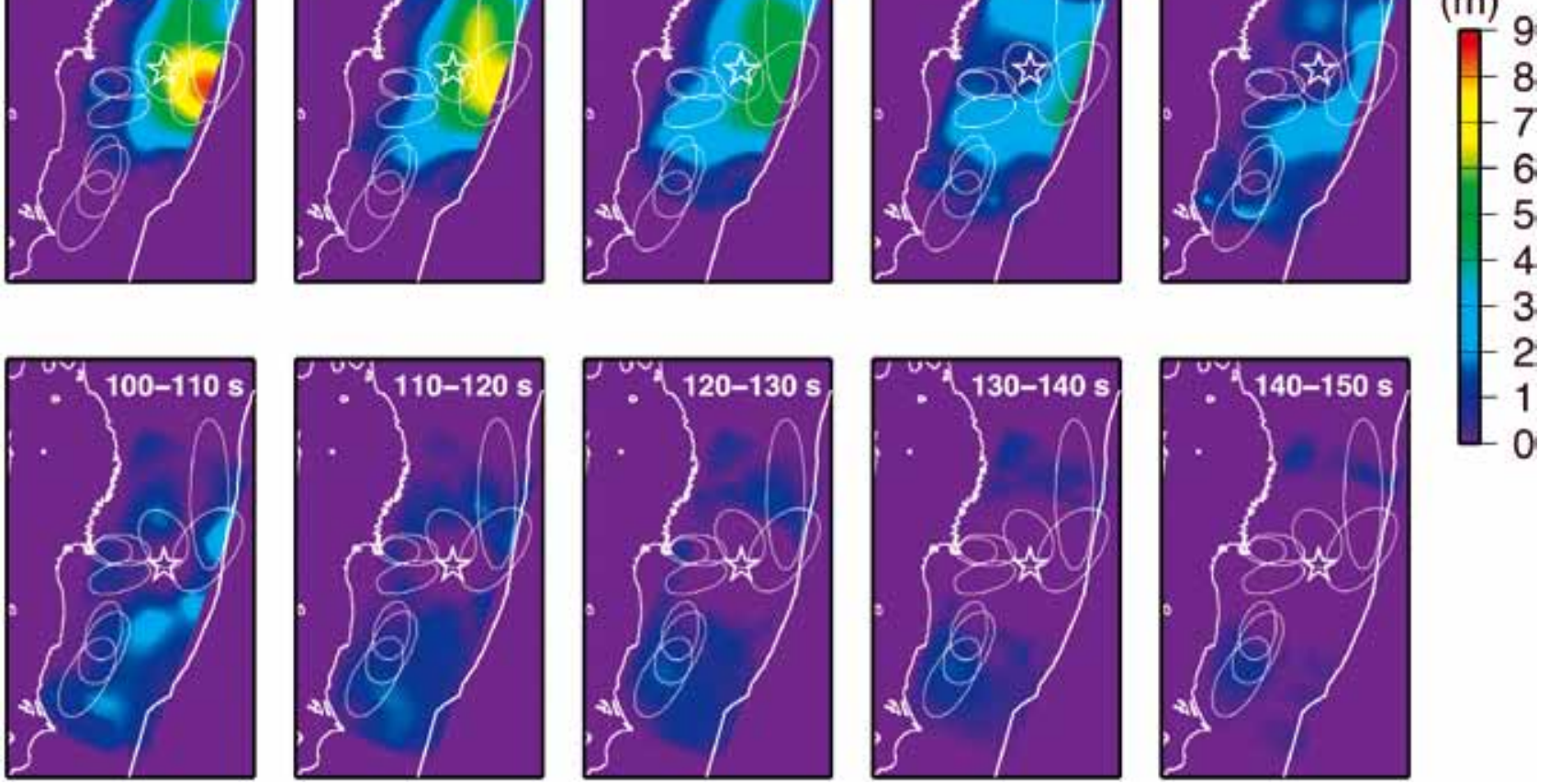

Fig. 4. Snapshots of slip distribution for each time period. Time after the initiation of the earthquake is shown on each panel. The star represents the hypocenter. The closed curves annotated with 1897, 1978, and 1896 correspond to the tsunami source regions of the 1897 far off Miyagi (M 7.7), 1978 off Miyagi (M 7.4), and 1896 Sanriku (M 8.2) earthquakes, respectively. Tsunami source regions of other large historical earthquakes in this area are also shown as thin closed curves (modified from Headquarters for Earthquake Research Promotion [http://www.jishin.go.jp/main/index-e.html]).

計算では，計算技術上の問題から層構造ではなく一様な半無 限弾性体を仮定しているため, かなりのバイアスがかかって しまっている. そこで, インバージョン解析の結果得られた 滑り分布を一旦モーメント解放量分布に変換した上で, この モーメント解放量から剛性率 $54 \mathrm{MPa}$ の一様な半無限弾性 体を仮定してすべり量を求め，応力降下量を計算し直した結 果が Fig. 6b である. 2 種類の方法で計算した応力降下量は, 媒質の弾性率コントラストが大きいことを反映して，かなり 大きく異なってしまっている. このうち，陸側に近い深部で は，(a)を約 3 割増(70/54 倍)したものが(b)とほぼ一致し ており，(b)の結果で概ね正しい，浅部および震源付近につ いては, 多層構造弾性媒質の振る舞い (Fukahata and Matsu'ura, 2005) も参考に考察したところ, 正解は (a) と (b)の 間で，(b)寄りにあると考えられる. 特に浅部においては (a) からの乘離が大きい. 結局のところ, 海溝から震源付近の応 力降下量は, おおよそ $10 \mathrm{MPa}$ 程度と推定される. 断層面 全体の平均の応力降下量は $6 \mathrm{MPa}$ である.

Fig. 4 より, 地震発生後ほぼ速やかに震源の海溝側と陸 側の双方に顕著な破壊が伝播している. 陸側では 20 秒前後 から 1978 年宮城県沖地震の震源領域 (Umino et al., 2006) 


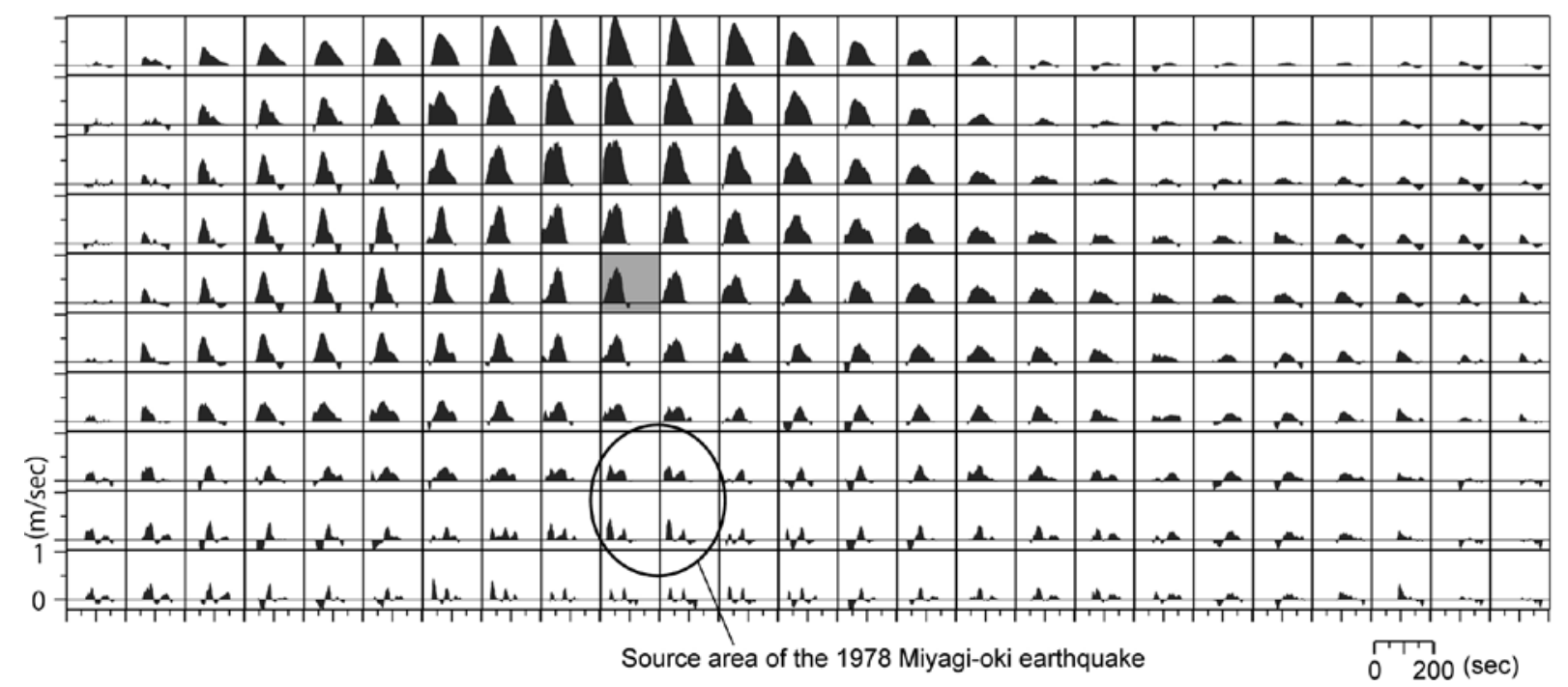

Fig. 5. Slip-rate function at each subfault. The origin of the horizontal axis at each subfault is taken to be the initiation of the earthquake. The subfault that includes the hypocenter at the center of the fault patch is hatched. The rigidity of each layer used in the inversion analysis is shown at the right of the figure. Poisson's ratio is 0.25 in every layer.

(a)

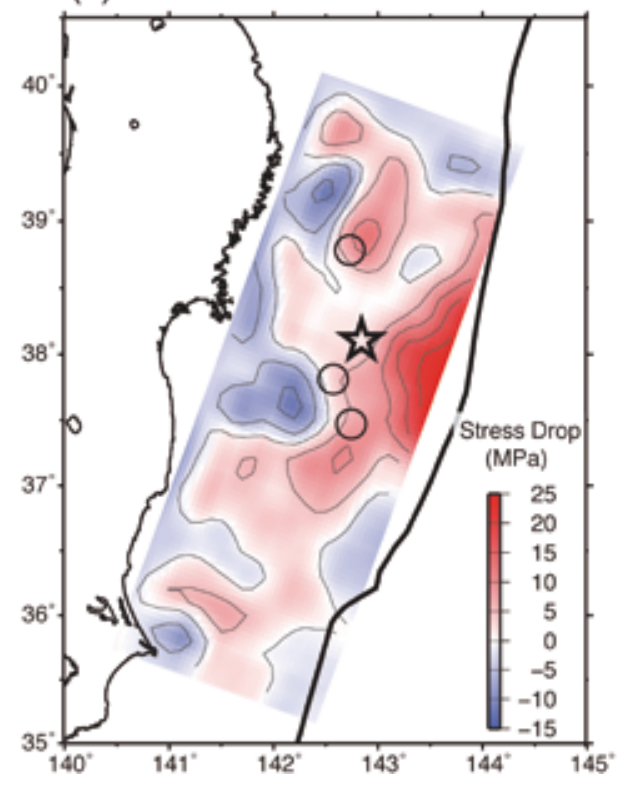

(b)

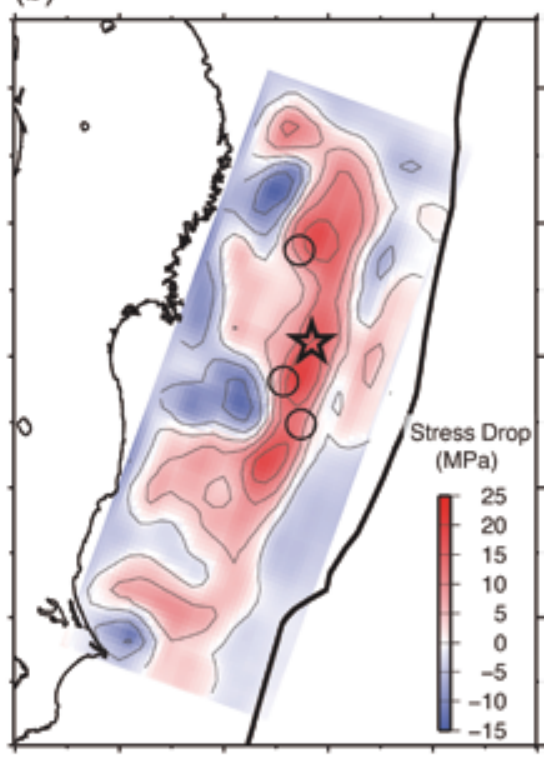

Fig. 6. Static stress drop for an average slip direction, calculated from the slip distribution (a) and the moment release distribution (b), under the condition of a homogeneous elastic half-space. Because of the rigidity contrast, the stress drop distributions (a) and (b) are quite different. The true stress drop estimated from the inversion result is considered to be close to (b) in the down-dip source region and intermediate between (a) and (b) (roughly $10 \mathrm{MPa}$ ) from around the hypocenter to near the trench (see the text for further discussion). The average stress drop over the fault plane is $6 \mathrm{MPa}$. The star represents the hypocenter. Also shown are locations of the low-angle normal fault aftershocks (black circles) at approximately the depth of the plate interface.
の破壊を開始し，大きなモーメント速度を持つ(Fig. 5). 35 秒頃から一旦速度が減少するが，その後再び加速して 80 秒 過ぎまで滑り続けた. 一方, 海溝側に伝播した滑りは 1897 年の宮城県はるか沖の地震の津波波源域を破壊し, $0.5 \mathrm{~m} / \mathrm{s}$ を越す速度で 50 秒以上もすべり続け，その後 30-40 秒間 かけて減速した. また, 地震の破壊開始後 50 秒頃からは破 壊が南北に伝播し始め, 約 100 秒で茨城県沖に達し，150 秒頃に停止した.

以上が, Yagi and Fukahata(2011a)で得られた結果であ る. 得られた破壊過程モデルは，長周期から短周期成分に至
るまで，観測された地震波形を良く説明する(Fig. 7)。しか し, 観測データとよく合うからといって, インバージョン解 析で得られた結果が信頼できるという保証はない(深畑, 2009). 以下本節では他の解析結果や観測デー夕との比較を 行い, 推定された滑り分布と破壊過程の妥当性について考察 する.

\section{2. 滑り分布についての考察}

震源よりも海溝寄りに滑りのピークを持ち, 最大滑り量が 数十メートルに達するというのは, 津波(例えば, Fujii et al., 2011) や強震動も含む多くのインバージョン解析結果に 

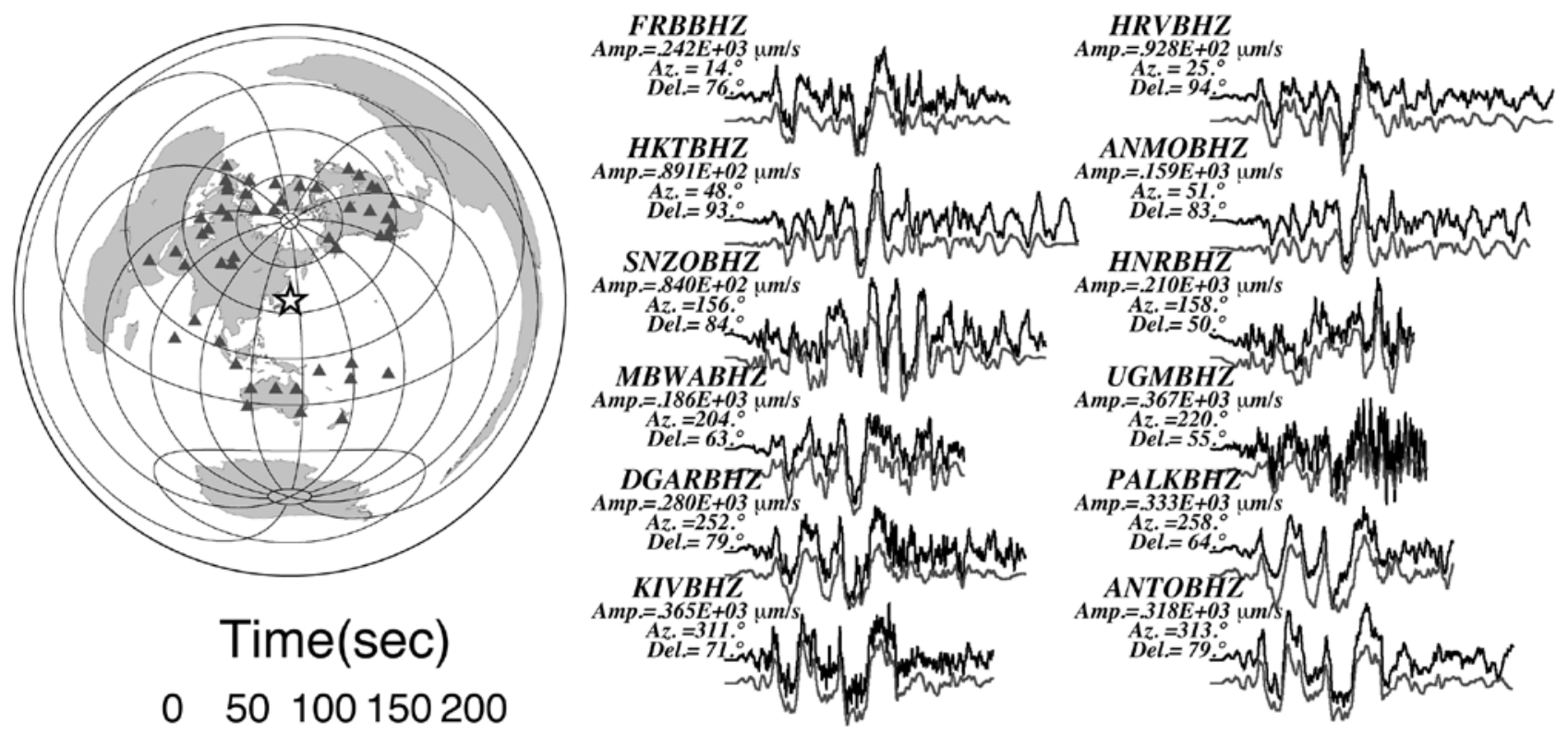

Fig. 7. Comparison between the observed (top) and synthetic (bottom) waveforms with the station distribution. The station code, maximum amplitude, azimuth, and distance from the epicenter are given at the upper left of each waveform.

共通して見られる特徵であり, 海底での地殼変動観測結果 (Sato et al., 2011) とも調和的である. しかし, それに次ぐ 滑り分布の特徵となると, 解析結果ごとに大きな違いが見ら れる. 主要な相違点は, 海溝沿いに南北に長く大滑り域が分 布するか (Lay et al., 2011; Lee et al., 2011; Shao et al., 2011; Suzuki et al., 2011; Yoshida, K. et al., 2011; Yoshida, Y. et al., 2011 (近地)), 宮城・福島・茨城沖などで 陸に近い領域にも大きな滑りが存在するか (Yagi and Fukahata, 2011a; Yoshida, Y. et al., 2011 (遠地); Yue and Lay, 2011)である.

まず，全体的な滑り分布の妥当性を検証するために，Fig. 1 の滑り分布から計算した地殼変動を国土地理院の GPS データ (Miyazaki et al., 2011) および海上保安庁の海底地 殼変動データ (Sato et al., 2011) と比較した (Fig. 8). 計算 結果と観測デー夕は概ね整合しており, Fig. 1 はもつとも らしい滑り分布の必要条件を満たしていると言える. ただ し, 計算で得られた福島県沿岸地域の変位量は明らかに大き く, 福島県沖の滑り量が過大に見積もられてしまっているこ とを示している.

繰り返し宮城県沖地震を引き起こしている領域が今回の大 地震で滑つたか否かは今後の地震発生予測に直接的に関わる 重大な問題だが，まず強震動生成領域の推定 (浅野・岩田, 2011) や繰り返し地震の解析 (東北大学大学院理学研究科, 2011)などからは顕著な滑りが生じたことが示唆されてい る. GEONET に海上保安庁の海底地殼変動デー夕も合わ せた余効変動の解析 (小沢, 2011) でも，すべりがほほ陸域に 沿って生じており, その直上の宮城県沖地震のパッチで顕著 な地震滑りが生じたとする考えと調和的である. なお，より 細かく見ると, Yagi and Fukahata(2011a)の解析で応力が (a)

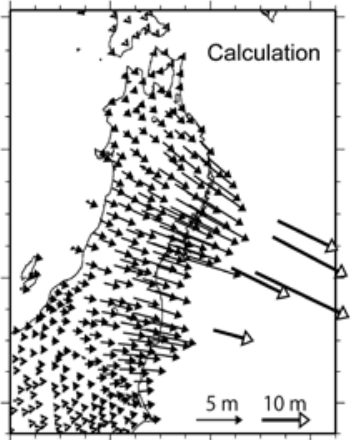

(c)

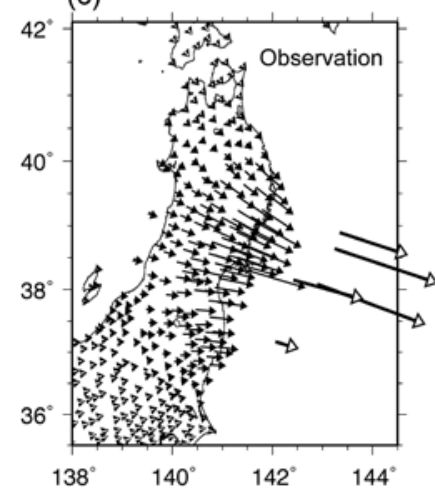

(b)

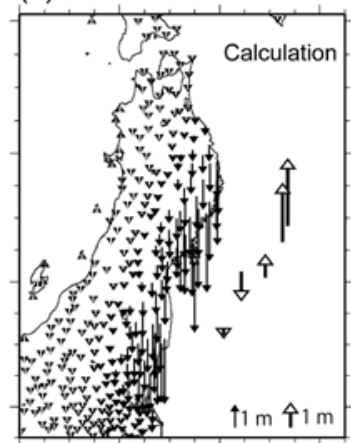

(d)

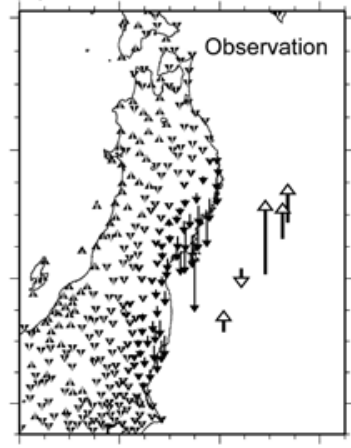

Fig. 8. Comparison between the synthetic (top) and observed (bottom) displacement vectors at the GPS stations. Horizontal (left panel) and vertical (right panel) synthetic displacements are calculated from the total slip distribution shown in Fig. 1. Observed data on land (solid arrow) and in the sea (open arrow) are from Miyazaki et al. (2011) and Sato et al. (2011), respectively. 
増加したところ (Fig. 6) で余効変動が大きくなっている傾向 も見られる. また, 後述するように $1 \mathrm{~Hz}$ GPS デー夕の解 析からも宮城県沖地震のパッチ周辺で顕著なモーメント解放 が起こったことが推定される. 以上のことを考え合わせる と, この領域が今回の地震で大きく滑ったことはほぼ確実で あろう.なお，海溝沿いに長く大きな滑りを推定した結果で も，宮城県沖地震のパッチには大きな滑りを求めたものが多 $<$ (Lay et al., 2011; Lee et al., 2011; Shao et al., 2011; Suzuki et al., 2011)，そこでの滑りが小さい解析結果は少 数である.

福島・茨城沖には, 地震開始後しばらくしてから破壊が伝 播したため, 地震波形インバージョンの解析精度は一般に悪 くなる，一方，津波は地震波よりも伝播速度がずつと遅いた め, 福島・茨城沖の滑りが, 福島以南の津波の第一波に対応 する. 津波データをインバージョン解析した Fujii et al. （2011）によれば，福島・茨城沖 50-100 km ほどの所に比 較的大きな滑りが求められている. 繰り返し地震はその周囲 を取り囲むように分布しており (東北大学大学院理学研究科, 2011), 両者の解析は調和的である. 余震のメカニズム解 (Asano et al., 2011)からも, プレート境界付近における逆 断層型の地震がこの地域で沿岸部と沖合遠くに多く分布する 一方, 沖合 50-100 km くらいの範囲にはぽっかりと穴が空 いたように少なくなっている. 強震動の解析結果 (浅野・岩 田, 2011) は, ここでも福島・茨城沿岸に強震動生成領域を 求めている. 地震発生後すぐの余震 (Fig. 1) も沿岸部に多い. 結局のところ, 福島・茨城沖で海溝沿いにしか大きな滑りが ないとすると不整合なことが多く，おそらくは繰り返し地震 や逆断層型地震の分布で穴が空いているところで大きな滑り があったと推測される．福島・茨城沖の海溝沿いに長く大滑 り域が求まっている解析結果が少なくないのは, Fig. 2 で 示したようにグリーン関数の誤差を無視したために生じた擬 似的なものであろう.

なお，宮城県から三陸沿岸にかけて，GPS と比較した変 位量(Fig. 8)が系統的に大きくなってしまっているが，それ はプレート境界の形状が効いているだろう。解析では簡単の ため傾斜角 $12 \circ$ の 1 枚の平面断層を仮定したが，実際のプ レート境界は沿岸近くではもつと高角度でより深部に位置す る. そのため, 滑り分布からそのまま地表変位を計算する と, 変位量 (特に沈降量)がやや大きくなってしまうという問 題がある.この解析よりも精密な議論を行うには, 現実的な プレート境界形状を導入することが不可欠だろう.

\section{3. 破壊過程についての考察}

モーメント速度関数 (Fig. 3) が，35 秒付近に肩を持ち, 約 70 秒でピークを打って, およそ 150 秒後にゼロに戻ると いうのは, 近地強震動も含め (Suzuki et al., 2011; Yoshida, Y., 2011)，ほぼ全ての波形解析結果 (Ammon et al., 2011; Hayes, 2011; Lay et al., 2011; Shao et al., 2011; Yagi and Fukahata, 2011a; Yue and Lay, 2011) に共通す る特徵である. つまり, モーメント速度関数の上記 3 つの 特徴は非常に信頼性が高いと考えられる．60-80 秒に海溝 寄りの地域で非常に大きな滑りが発生していることも，同様
に共通している. したがって，モーメント速度関数の約 70 秒のピークは, この海溝寄りの大滑りが大きく寄与したもの だろう.

一方, 初期の破壊がごのように進展したかは, 研究者によ り結果が大きく異なる. 初期の破壊伝播がどのようであった かは, この地震を理解する上で決定的に重要なポイントで, 東北沖大地震を再現しようとする数值シミュレーションで も，この初期破壊伝播形態によりモデル化が大きく左右され 得る. しかし, 破壊開始から特に最初の 30-40 秒間の滑り は, 解析結果間の差異が大きいので，以下やや長くなるが, この問題について議論する.

最初の 30-40 秒間, いくつかの解析ではすべりが震源付 近で継続している(Shao et al., 2011; Yoshida, K., 2011; Yoshida, Y., 2011 (近地)). 一方, Yagi and Fukahata (2011a)では海溝寄りと陸側の両方でモーメント解放が大き くなっており, 陸に近い領域 (Ide et al., 2011; Koketsu et al., 2011), もしくは海溝に近い領域 (Lee et al., 2011)の みが大きくすべるというインバージョン結果も出されてい る. 関東地方に展開された MeSO-netのデータを用いた back projection 解析 (Honda et al., 2011) では, 陸側と海 側の二つに滑りが分離していることが見てとれる．MeSOnetのデー夕は, 空間的な位置関係から, along-arcでなく across-arc の方向に分解能が良いという特徵がある. 強震 動データの解析では, 最初の顕著な強震動の生成領域が震源 よりも陸側, 1978 年宮城県沖地震の震源域付近にほぼ共通 して求められている(浅野・岩田, 2011; Suzuki et al., 2011; Yoshida, Y., 2011). ただし, 近地強震動デー夕は, across-arc の方向の分解能が限られる上，必ずしも大きな 滑りが生じなくとも, 滑りの加速度さえ大きければ振幅が大 きくなるという弱点がある.

国土地理院によって観測された $1 \mathrm{~Hz}$ GPS のデー夕はこ の問題に重要な制約を与える(Fukahata et al., 2011). たと え高密度でサンプリングしていても GPS デー夕は変位を記 録するので(強震計は, 加速度ないしは速度を記録), 地震に よるモーメント解放量, つまりは滑り量とより直接的に関係 付けられるからである. Fig. 9a に三陸沿岸の $1 \mathrm{~Hz}$ GPS の 海溝軸に直交する方向 $\left(\mathrm{N} 110^{\circ} \mathrm{E}\right)$ の変位デー夕を示す (東南 東向きが正)。この図から, 牡鹿では地震開始後 30-55 秒の 間に $1.5 \mathrm{~m}$ ほど変位した後 20 秒近く停滞し, 再び 35 秒ほ ぞかけて最大変位の $6 \mathrm{~m}$ に達していることが分かる. 一方, 宮古では地震開始後 1 分近く経ってから比較的顕著な変位 が始まり，およそ 2 分で変位がピークを打つ. 気仙沼と釜 石は, 牡鹿から宮古への遷移的な振る舞いを示している.こ こで注目すべきは, 牡鹿では 1 分前後に明瞭な変位の停滞 が見られる(宮古ではそれに対応する変位の停滞がない)こと と, 牡鹿と宮古の変位の時間差がピークについては 10 秒強 である一方, 顕著な変位開始については約 25 秒とはっきり と大きいことである. これらのことは, 牡鹿の最初の $1.5 \mathrm{~m}$ の変位とその後の変位の原因が, 別の場所に求められなけれ ばならないことを意味する. 牡鹿の後半の大変位は, 前述の 状況から, その主因は海溝寄りの大滑りと考えられる。 一 

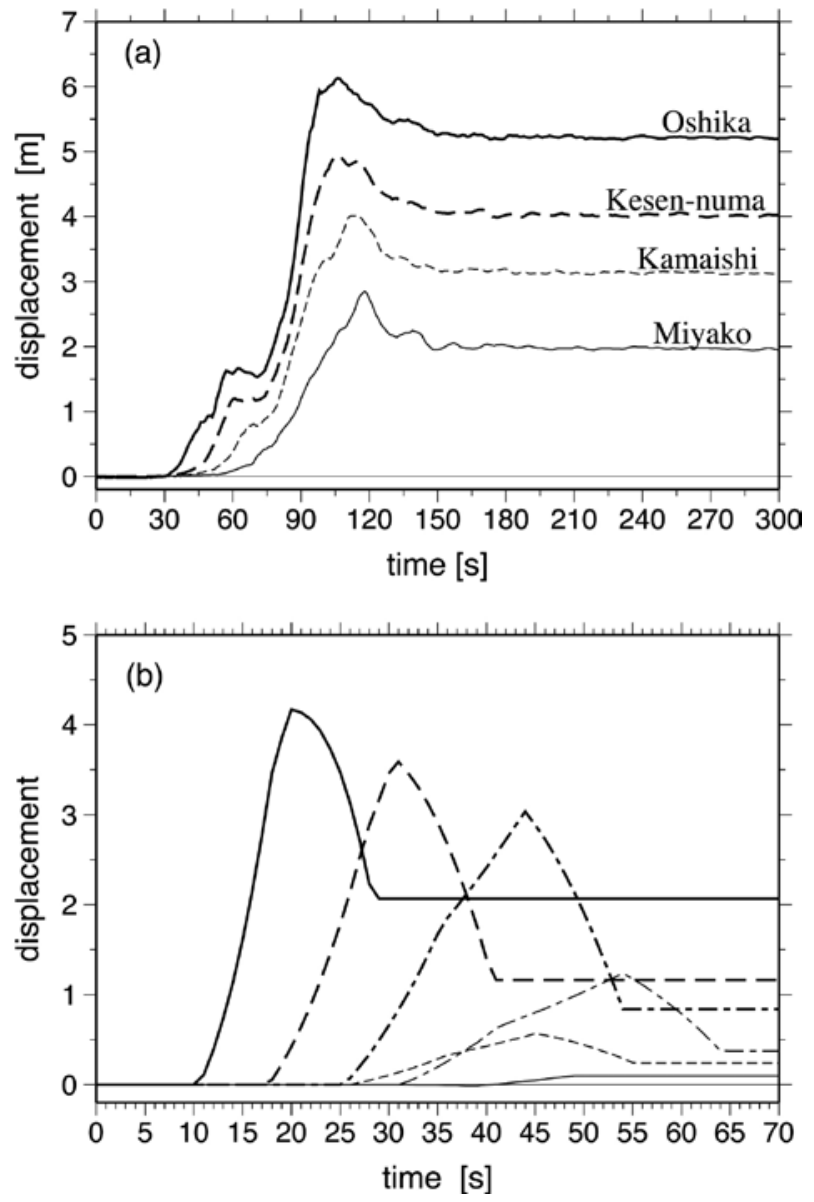

Fig. 9. (a) Time series of surface displacements observed at GPS stations in Sanriku sampled at $1 \mathrm{~Hz}$. The displacement component vertical to the trench axis $\left(\mathrm{N} 110^{\circ} \mathrm{E}\right)$ is shown. (b) Computed displacements at Oshika (bold lines) and Miyako (thin lines) caused by dislocation sources near the coast (solid line), at the hypocenter (broken line), and near the trench (chain line) on the fault plane. The surface projection of the source locations is shown in Fig. 1.

方, 牡鹿の前半の変位は宮古にはほとんどその影響を及ぼし ていないことから, 震源よりももつと陸に近いところ, 例え ば 1978 年宮城県沖地震の震源域付近にあることが推定され る.

これらの推定は, シンプルな動的変位の計算からも裏付け られる (Fig. 9b)，計算では，簡単のため，一様等方な無限 弾性体を仮定し, P 波速度 $7.0 \mathrm{~km} / \mathrm{s}$, ポアソン比 0.25 とし た. そして, Fig. 1 に示す震源を含む 3 箇所に, 10 秒間一 定の速度で増加する地震モーメント(つまり, ボックス型の モーメント速度関数)を置き, 牡鹿 (太線)および宮古 (細線) での動的変位を計算した．動的変位の計算では，遠地項は無 視し，近地項と中間項 (Aki and Richards, 1980; 松浦, 1996)の夕評価した．各震源に置く地震モーメントは純粋な 逆断層型(すべり方向が $\mathrm{N} 110^{\circ} \mathrm{E}$ ) とし，その值は適当に規 格化している. ただし，与えるモーメントの比は陸側から海 溝寄りに向かって $1: 2: 4$ とした.

計算結果から, 震源付近 (破線)で滑つた場合, 宮古では牡
鹿から約 10 秒遅れでその数分の 1 の変位が生じる一方, 陸 側(宮城県沖地震のパッチ；実線)での滑りに対してはほとん ど変位が生じない，加えて, 陸側での滑りに対し牡鹿では顕 著な変位の逆戻りが生じるが，宮古にはそれが現れない。し たがって, 牡鹿の初期の変位は震源付近ではなく宮城県沖地 震のパッチ付近が滑つたものであり, モーメント速度関数の 35 秒付近の肩も, 震源付近ではなく陸側でのモーメント解 放が主因と考えられる. それらは, Yagi and Fukahata (2011a)のインバージョン解析で得られた宮城県沖地震の パッチにおけるモーメント速度関数の増加および減少 (Fig. 5) とぴったり符合する. ちなみに, 変位が逆戻りするのは, 厳密には角度に依存するものの, 遅れて伝播する $\mathrm{S}$ 波の中 間項が近地項や $\mathrm{P}$ 波の中間項に対し概ね逆方向の変位を持 つためであり，モーメント速度関数が急激に減少するときに この変位の逆戻りが顕著に現れる. Fig. 9aにおいて各観測 点で変位が最大值を取った後に大きく逆戻りしているのが見 られるが，これらも $\mathrm{S}$ 波の中間項のためと考えられる.

なお, $1 \mathrm{~Hz}$ GPS データのより詳しい解析 (Fukahata et al., 2011)によれば，海溝寄りで顕著なモーメント解放が始 まったのは 35 秒以降であり, 震源から陸側と海溝側の双方 に破壊が伝播したという点では Yagi and Fukahata(2011a) の結果と一致しているものの, タイミングについては 10 秒 程度その解析結果よりも遅い. 海底地震計を用いた震源再決 定 (日野他, 2011)によれば震源位置が気象庁の決めたものよ りも $10 \mathrm{~km}$ ほど西に動くので(その分, 海溝への破壊伝播が 遅れる)，一つにはその効果が効いているだろう。また，ま ず陸側で大きくすべり, 次いで海溝寄りで大きな滑りが生じ るというのは, Ide et al. (2011)の主張と合致する. ただし, 彼らの結果では逆に滑りのタイミングは遅れているように見 える.

\section{絶対歪みの解放とその意義}

現在の科学の水準として, 地震波形をデータとして地震の 破壊伝播過程を求めるインバージョン解析では, 残念ながら 研究者により相当違つた結果が得られているのが実情であ る. しかし, 前節で詳細に論じたとおり, グリーン関数の誤 差を明示的に取り入れる最新の手法で解析した Yagi and Fukahata (2011a)の結果は, 福島沖の滑りが過大であった り海溝寄りのすべり開始が 10 秒程度早いといつた問題はあ るものの, 滑り分布の全体的特徵やモーメント速度関数, 破 壊の伝播過程などが, 他の観測デー夕等により全般的に良く 裏付けられていることが分かって頂けたと思う.ここで, 東 北沖大地震の主破壊の特徽を改めてまとめると, 海溝寄りに おける長大な滑り (最大 $50 \mathrm{~m}$ )・長いすべり時間(最大 90 秒) ・比較的大きな応力降下 (約 $10 \mathrm{MPa}$ ) ということになる.

応力降下量は, 海溝型地震については平均約 $3 \mathrm{MPa}$ とさ れており (Kanamori and Anderson, 1975), インバージョ ン解析の結果得られた断層面全体の平均で $6 \mathrm{MPa}$, 震源か ら海溝付近でおよそ $10 \mathrm{MPa}$ というのは, それを上回る. また，ある地点における滑りの継続時間は，経験則 (Geller, 1976)によればマグニチュード 9(M 9) の地震でもおよそ 
30 秒であり, 90 秒というのは上述の解析の不正確さを考慮 に入れても有意に長い. 例えば, 2010 年チリ地震 (M 8.8) は, 断層サイズは東北沖大地震と同程度だが, 各地点の滑り の継続時間は最大でも 24 秒に過ぎない(Delouis et al., 2010). 滑り速度については通常の地震と特段変わらないも のの，断層面が通常よりもかなり長い時間すべり続けるとい うことは, 普段よりもずつと多くの歪みや応力を解放すると いうことであり, そのためには断層面上の摩擦強度が地震時 に著しく低下することが必要であろう。こういつた摩擦強度 の低下は実験的に多数報告されており(例えば, Tsutsumi and Shimamoto, 1997), それらに基づいた東北沖大地震 の現象論的なモデル化も既に試みられている (Shibazaki et al., 2011). 摩擦強度低下の原因としては, 断層すべりに伴 うメルトの生成(McKenzie and Brune, 1972) や flash heating (Rice, 2006)などいくつかのメカニズムが考えられ るが, 断層中の間隙流体の摩擦発熱による膨張 (thermal pressurization, 以下 TP と略記) はその有力な候補である (Sibson, 1973; Bizzari and Cocco, 2006; Mitsui et al., 2012). 岩石実験や地質学的なデータからも沈み込み帯浅部 の環境下でTPが有効に働くことが示唆されている (Faulkner et al., 2011; Yamaguchi et al., 2011). TP 等 によって断層の摩擦強度が著しく低下することにより，長大 な滑りが生じ，それが引き金となって広大な領域が大きく 滑つたのであろう．極端な例が宮城県沖地震のパッチで，一 旦すべり速度が大きく低下した後に再び増加し, 長い距離す ベった (Fig. 5). 前半の滑りが想定宮城県沖地震の歪みを解 放したもの, 後半の滑りが海溝寄りの大滑りに引きずられて 生じたものと考えれば, この奇妙な振る舞いが無理なく理解 できる。

摩擦強度が極端に低下したことは, 地震のメカニズム解の 変化からも裏付けられる (Asano et al., 2011; Hasegawa et al., 2011)。本州は，伊豆の衝突帯を除いては，ほぼ東西圧 縮の応力場で, 東北日本は海域部分も含めその典型であった (Terakawa and Matsu'ura, 2010). しかし，Fig. 10 に示 すように, 東北沖大地震後は, 発生する地震のメカニズム解 が劇的に変化した. 福島県沿岸では正断層地震が頻発し, 長 野県北部で発生した地震は, 以前と比べ $45^{\circ}$ ほど圧縮主応 力軸が回転している. 本震で大きく滑つた領域の上では多く の正断層地震が発生し, さらに Fig. 6 にも示したようにほ ぼプレート境界の深さで低角の正断層地震もいくつか観測さ れている(Ide et al., 2011). Yagi and Fukahata(2011a) はその最大のもの (M 6.6)について波形インバージョン解析 を行い, 共役な高角の断層面ではなく, 確かにプレート境界 とほぼ一致する低角の断層面で正断層の滑りが起きたもので あることを確認した.

プレート境界では海洋プレートの沈み込みに伴い歪みや応 力が蓄積されている. 時々起こる海溝型地震は, その歪みや 応力を解放するものである (Fig. 11)。しかし, 一般に, 歪 みや応力の絶対レベル, 即ち絶対歪みや絶対応力を知ること は容易でない. 測地観測から推定されるのは歪みの絶対值で はなくその変化であり, 地震デー夕を解析することによって

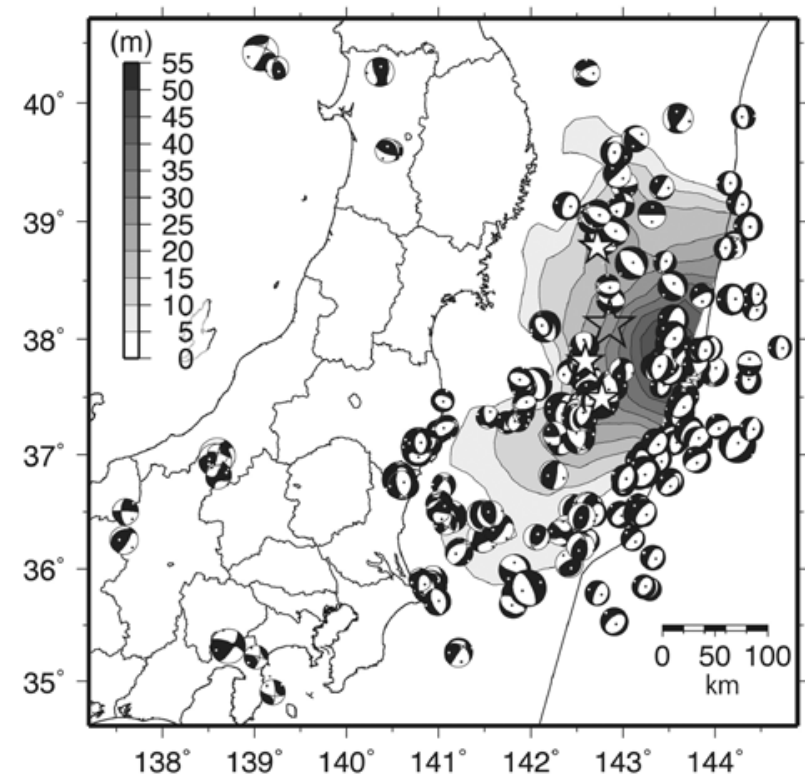

Fig. 10. Distribution of focal mechanisms of shallow aftershocks $(<10 \mathrm{~km})$ during one month after the mainshock determined by National Research Institute for Earth Science and Disaster Prevention (NIED) with the inverted total slip distribution of the mainshock. Open stars show the locations of the low-angle normal fault aftershocks at approximately the depth of the plate interface derived from the Global CMT catalog [http://www.globalcmt.org].

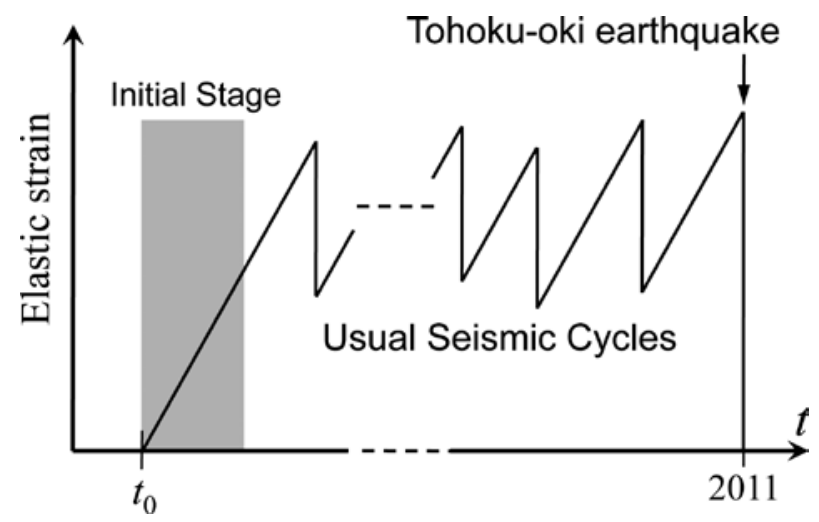

Fig. 11. Schematic image of temporal strain change on the plate interface. In the beginning of plate subduction, elastic strain accumulates linearly. After the initial stage, elastic strain is released from time to time (usual seismic cycles), but it is difficult to estimate its absolute level. The 2011 Tohoku-oki earthquake appears to have exceptionally released roughly all accumulated elastic strain.

得られるのも, 地震による応力の変化に過ぎないからであ る. サンアンドレアス断層を舞台に繰り広げられてきた応力 の絶対値をめぐる論争(例えば, Scholz, 2000)は, この問題 の難しさを示している. M 8 クラスを含むほとんどの地震 では, 今回のように地震の前後で顕著に応力場が変化するこ とはない. 宮城沖における地震メカニズムの応力インバー ジョン解析の結果は, 2000 年代に入っていくつか起こった 
(a)

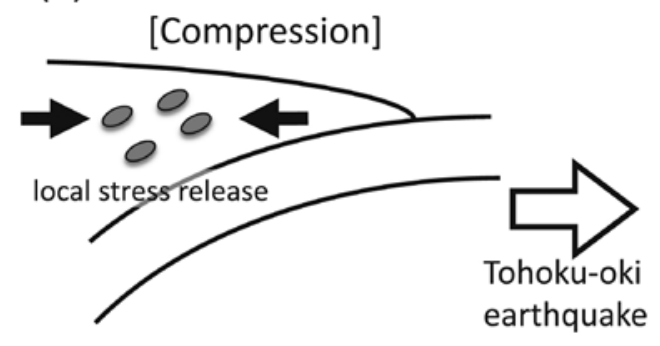

\section{[Neutral]}

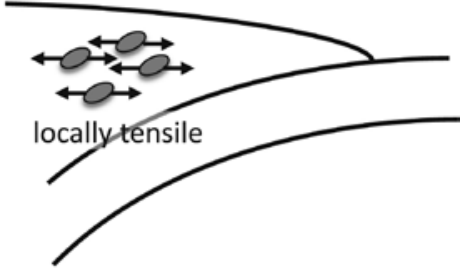

(b)

[Tension \& Compression]

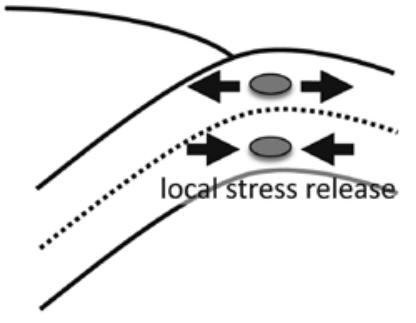

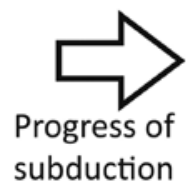

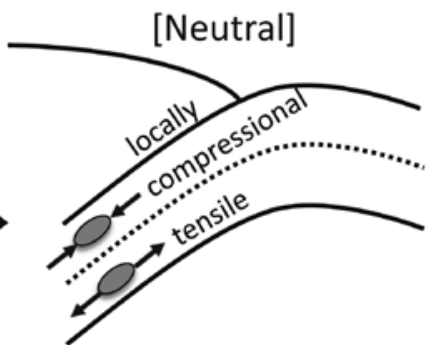

Fig. 12. (a) Schematic image of the occurrence of tensile earthquakes in a neutral stress regime. Compressional stress had prevailed in the fore-arc of the Tohoku district until the 2011 Tohoku-oki earthquake, and the compressional stress had of locally released by inelastic processes (left). After the 2011 Tohoku-oki earthquake the compressional stress has almost completely vanished, and the stress regime may be nearly neutral. However, the stress can be locally tensile in places where inelastic processes had already released the compressional stress (right). (b) Similar situation for the double-planed deep seismic zone. Tensile and compressional stresses in the oceanic plate around the trench may be locally released by inelastic processes (left). Seismic activity can occur in a neutral stress regime at depth, where the oceanic slab recovers an almost straight shape (right).
この地域の $M 7$ クラスの地震によって, 応力場がほとんど 全く影響を受けなかったことを示している(Hasegawa et al., 2011). 要するに, 通常の海溝型地震による応力解放は, 蓄積されている応力の一部に留まる。（一つの例外は 1968 年十勝沖地震 $(M 8.2)$. 多くの正断層型の余震が発生した (Kanamori, 1971)。2010 年チリ地震 (M 8.8) でも北部の 大滑り域の上盤側で, 多数の正断層型余震が発生している (Lange et al., 2012). )

しかし，福島県沿岸や長野県北部を初めとする広域にわた る地震メカニズム解の大変化は, プレート境界で蓄えられて きた絶対歪みおよび絶対応力の少なくともかなりの部分が解 放されたことを意味している. プレート境界付近の深さでプ レート境界とほぼ平行な低角の正断層地震が複数発生してい ること (Fig. 6) は, 少なくとも局所的に今回の地震で滑り過 ぎが生じたことを示している. さらに，本震で大きく滑った 領域の上で多くの正断層地震が発生していることも, プレー 卜境界で蓄積されてきたほぼ全ての歪みや応力が解放された ことを強く示唆する (Fig. 11). 実際に, 地震のメカニズム 解をデータとして応力インバージョン解析を行った結果 (Hasegawa et al., 2011) も，ほぼ全ての応力が解放された と結論付けている. このような大規模な絶対応力の解放は, 摩擦強度の極端な低下によってもたらされたものと考えら れ, インバージョン解析の結果得られた我々の破壊モデルと 大変調和的である.

なお，一つ注意すべきこととして，正断層地震が多く発生 しているからといって，プレート境界の広い範囲で滑り過ぎ が起こり, この地域の応力場があまねく正断層的になつたと は限らないということがある. その理由として，まず一つに は地形的な効果がある. 山脈の稜線近くにはしばしば線上凹 地(二重山稜)が発達しているが，それは山脈の自重によって
生じた伸張応力に起因する正断層運動によるものである (町 田, 2006). それと同様の理由により, 島弧で高く海溝で低 いという地形的な効果により, プレート境界で滑り過ぎが起 こらなくても伸張の応力が発生する. 忘れられがちなもう一 つの効果としては，地殼の非弾性的性質に起因するものがあ る. 前述のとおり, この地域は長らく圧縮応力場だった. そ うすると, その圧縮応力を解放するために地震など非弾性的 な変形が発生し, 局所的に応力を解放するということが起こ る. しかし, 今回の地震によって突然圧縮応力がなくなる と, その局所的に応力を解放していたところは, 逆にマイナ スの圧縮応力 (つまり, 伸張応力) となる (Fig. 12a).このよ うなことは実際に沈み込む海洋プレート内部で起こっている と考えられる (Fig. 12b). 東北日本を初めとするいくつかの スラブでは二重深発地震面が観測されているが, 上側は圧 縮, 下側は伸張のメカニズムを持つ(Hasegawa et al., 1978）。この原因として，スラブが上部・下部マントル境界 で下に凸に曲げられるためという考えがあるが，下に凸にな る深さと二重深発地震が起こっている深さには大きな開きが あり,この説明には無理がある. むしろ, プレートは全体的 には弾性的に振る舞うため, 海溝付近で無理矢理に曲げられ たプレートは, ある程度以深では直線的な姿 (つまり中立的 な応力状態) に戻ろうとするものの, 局所的には曲がった状 態になじんでしまった部分があって, その部分がプレートが 真つ直ぐに戻るときに, 上述のメカニズムの地震を起こすのだ と考えられる(Engdahl and Scholz, 1977; 古賀ほか, 2012).

さて，もしも本当にプレート境界に蓄えられていた歪みが この地震によってほぼ全て解放されたならば，そのことは重 大な意味を持つ. まず一つには, この地震の応力降下量の解 析から絶対応力を見積もることが可能となる. これは, 通常 の地震では決して行えないことである. なお, 絶対応力の推 
(a) Distance along dip [km]

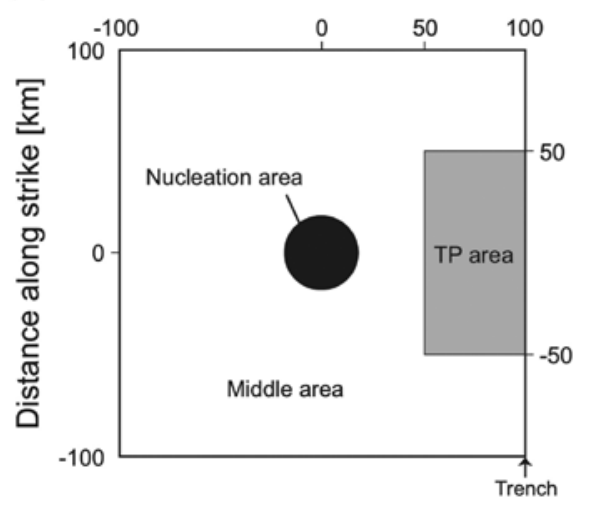

(b)

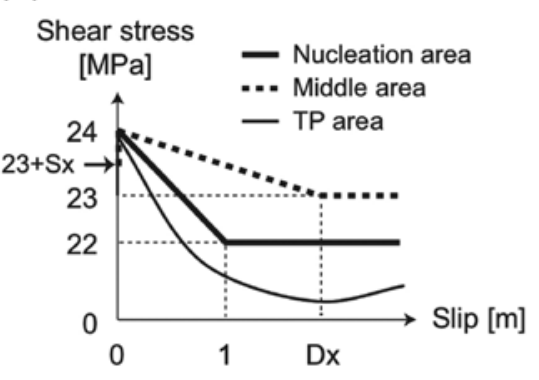

(c)

$\star \mathrm{M} 8.9$

O $\mathrm{M} 7.2-7.4$

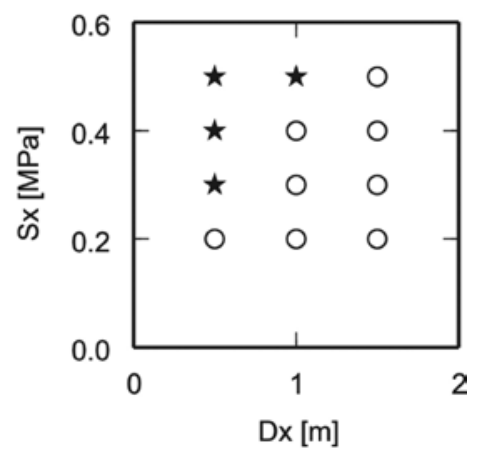

Fig. 13. (a) Fault model for a dynamic rupture simulation with thermal pressurization (TP). The rupture starts at the nucleation area and propagates through the middle area, reaching the TP area. (b) Evolution of shear stress in each area. In the nucleation area, the stress drop starts instantaneously following the linear slip-weakening friction (the residual friction is fixed). In the middle area and the TP area, the stress drop starts when the shear stress reaches the yield strength (24 MPa). The friction law in the middle area is also linear slip-weakening, but that in the TP area is a combination of TP and slipstrengthening, which can cause a nearly complete stress drop. (c) Computed results for the final moment magnitude as a function of initial stress $S x$ and the characteristic slip-weakening distance $D x$.

定は一般に容易ではないが，物理的に極めて重要な量である こともあり, 東北日本弧においても例えば, 地殼熱流量デー 夕(Furukawa and Uyeda, 1989), 島弧地殼の力のバラン 又 (Seno, 2009), 前述の 1968 年十勝沖地震の余震の解析 (Magee and Zoback, 1993)などから見積もられてきた. それらの推定結果は順に，20 MPa 以下，約 $20 \mathrm{MPa} ５$ MPa 以下であり, Fig. 6 で示される東北沖大地震の応力降 下量の見積もり，震源から海溝付近で約 $10 \mathrm{MPa}$ ，断層面の 平均で約 $6 \mathrm{MPa}$ とよく一致する. なお, 応力インバージョ ンを行った Hasegawa et al. (2011) は絶対応力の值を 21$22 \mathrm{MPa}$ と見積もっており, 我々の解析よりもやや大きいが おおよそ類似の結果と言えるだろう。

歪みがほぼ全て解放されたとすると, 更により重大なこと として, 大地震の周期性に疑問符が付くということがある. なぜなら，歪みをほぼ全て解放するには $\mathrm{TP}$ 等の効果により 断層面に働く摩擦強度の極端な低下が必要であると考えら れ, TP 等の効果は強い非線形性, 即ち強い初期值依存性を 持つことが期待されるからである. Fig. 13 に TP を取り入 れた簡単な数值シミュレーションの結果を示す. 断層の動的 破壊過程の計算には, 周波数領域における境界要素法 (Day et al., 2005)に TP モデル (Bizzarri and Cocco, 2006; Mitsui and Hirahara, 2009)を組み込んだ手法を用いた. Fig. 13aのように海溝沿いに TPが強く効く領域を設け, 震源核 形成領域 (nucleation area) を少し離して配置した. 数值シ ミュレーションでは一様な無限弾性体を仮定しているため, 海溝には鏡像法を用いて疑似的な自由端境界条件(断層面の 傾斜方向に垂直な面に対する応力成分がゼロ)を与えてある. 各領域内では初期応力場はそれぞれ一定とし (Fig. 13b)，特 に Nucleation area では初期応力が降伏強度と等しい(正確 には，ほんのわずかに上乗せする)ように設定し，動的破壊 を人為的に開始させる. 断層上の各点において, せん断応力
が降伏強度を超えることですべりが生じ摩擦強度の低下が起 こる. 震源核形成領域や中間領域 (middle area) では滑りに 伴う摩擦弱化曲線をあらかじめ固定している一方, TP 領域 ではTPによる非線形な摩擦弱化が起こるとした(Fig. 13b). この時, Fig. 13c に示されるように, 中間領域にお けるちょつとした $(100 \mathrm{kPa}$ オーダーの) 初期応力の違いや 若干の摩擦パラメ夕の違いによって, 動的破壊がM 7 クラ スで終わったり $M 9$ クラスになったりする. なお, 本論文 の計算では, TP 領域まで高速破壊が到達すると, TP 領域 の大きな滑りに引きずられて設定した断層全体が破壊するよ うになっている. TP を取り入れたもう少し現実的な設定の 計算としては, Mitsui et al. $(2011,2012)$ を参照して頂き たい.

南海トラフを初めとして, 海溝型の大地震は繰り返し発生 してきたことが知られているが, 実はその周期性は決して良 くない，最も良く知られている南海トラフについて言えば, 最短の繰り返し間隔は 90 年で, 最長では 264 年である (Ando, 1975). 北海道の太平洋沿岸では津波堆積物が調查 されているが, その再来間隔は平均 450 年であるものの, 短い時には 100 年, 長い時には 800 年とこれまたばらつき が大変大きい (Sawai et al., 2009). 東北日本の太平洋沿岸 でも同様で, 再来間隔は 450 年から 800 年となっている (宾 倉ほか, 2010). 東北沖大地震の発生後, 巨大地震のスー パーサイクルの存在がクローズアップされてきた (Hori and Miyazaki, 2011; 池田・岡田, 2011). 確かに, 巨大地震は, 繰り返し発生してきたであろう. しかし, 断層面の破壊時に おける非線形的性質を考えると, 地震が周期的」に発生する ことには，疑問を持たざるを得ない，TPに影響を与える水 理学的性質も, 比較的容易に時間変化することが想像され る. そして実際に, これまでの発生履歷からしても, 周期的 と呼ぶのは難しく, せいぜいが擬周期的と呼ぶべきものであ 
る. 瀬野 (2012) も南海トラフ沿い大地震の非周期的振る舞 いに注目し, 固有地震的考えを否定した. ただし, 結局は安 政型と宝永型に二分したに留まり，周期性のドグマから離れ 切れてはいない.

地震は, 蓄積された歪みを短時間で解放する過程である. プレート境界では歪みの蓄積はプレート運動に伴い極めて定 常的に起こる. 一方, 歪みの解放過程はちょつとした状況の 違いにより大きく変化するのだろう，そのように考えると， 海溝型巨大地震が擬周期的に発生してきたことが無理なく理 解できる. そして，もしそうであるとすると，M9クラス の巨大地震の発生を予測することは，極めて難しい．

\section{ま と め}

2011 年東北地方太平洋沖地震については, 発生直後から 数多くの破壊伝播モデルが提出されている. それらのモデル の大部分は, 震源の海溝寄りに大きな滑りのピークを持つこ と, モーメント速度関数の概形 (Fig. 3) などの点で一致をす るが, 宮城, 福島, 茨城各県の陸側に近い領域の滑りの有 無, 地震開始から最初の $30-40$ 秒間の破壊伝播過程などに は大きな差異がある. 本稿では, $1 \mathrm{~Hz}$ GPS デー夕に関連す る簡単なモデル計算や繰り返し地震の分布などから，陸側に 近い領域にも比較的大きな滑りがあったこと，特に地震開始 後 20-35 秒くらいには, 1978 年宮城県沖地震の震源域付 近で顕著なモーメント解放があったことを論じた. グリーン 関数の誤差を明示的に取り入れる最新の手法で解析した Yagi and Fukahata (2011a)の結果は, 福島沖の滑りが過大 であることや海溝寄りのすべり開始が 10 秒程度早いという 問題はあるものの，全般的に信頼できると考えられる.

東北沖大地震の主破壊は, 長大な滑り (最大 $50 \mathrm{~m}$ ), 長い すべり時間(最大 90 秒), 比較的大きな応力降下(約 10 $\mathrm{MPa}$ ）という特徵を持つ. それらの特徵は, 断層面の摩擦強 度が地震時に極端に低下したと考えるとうまく説明が付く. 余震のメカニズム解が地震前と大きく変化したことも, 沈み 达むプレート境界面において東北沖大地震でほぼ全ての歪み が例外的に解放されたことを示し (Fig. 11)，摩擦強度の極 端な低下を裏付ける. 大地震時に摩擦強度が極端に低下する ならば，その非線形的効果から，大地震の周期的発生が疑問 視されることとなる，海溝型大地震が，決して周期的ではな く, むしろ擬周期的に発生していることは, この考えと調和 的である.

\section{謝辞}

$1 \mathrm{~Hz}$ GPS のデータは宮崎真一氏より提供頂いた．堀高峰 氏との議論は有益であり, 芝崎文一郎氏からは有用な情報を 頂いた． 西村直樹氏の協力, 查読者からのコメントにも感謝 する. 遠地実体波デー夕は米国地震学連合のデー夕管理セン ター(IRIS-DMC) より取得した. 震源位置は気象庁, モー メントテンソル解は防災科技研の F-net および Global CMT projectにより決定されたものを用いた. この研究は, 深畑および八木への科研費 (No. 21540428) の助成を受けて いる.

\section{文献}

Akaike, H., 1980, Likelihood and the Bayes procedure. In Bernardo, J. M., DeGroot, M. H., Lindley, D. V. and Smith, A. F. M., eds., Bayesian Statistics, University Press, Valencia, 143-166.

Aki, K. and Richards, P. G., 1980, Quantitative Seismology, Volume I, W. H. Freeman and Company, New York, 557p.

Ammon, C. J., Lay, T., Charles, J., Kanamori, H. and Cleveland, M., 2011, A rupture model of the great 2011 Tohoku earthquake. Earth Planets Space, 63, 693-696.

Ando, M., 1975, Source mechanisms and tectonic significance of historical earthquakes along the nankai trough, Japan. Tectonophysics, 27, 119-140.

浅野公之 - 岩田知孝 (Asano, K. and Iwata, T.), 2011, 2011 年東北 地方太平洋沖地震の広帯域強震動生成々震源破壊過程の関係, 日 本地震学会 2011 年度秋季大会講演要旨 (Seismol. Soc. Japan, 2011, Fall Meet., Abstr.), 5.

Asano, Y., Saito, T., Ito, Y., Shiomi, K., Hirose, H., Matsumoto, T., Aoi, S., Hori, S. and Sekiguchi, S., 2011, Spatial distribution and focal mechanisms of aftershocks of the 2011 off the Pacific coast of Tohoku Earthquake. Earth Planets Space, 63, 669-673.

Beresnev, I. A., 2003, Uncertainties in finite-fault slip inversions: to what extent to believe? Bull. Seismol. Soc. Amer. 93, 2445-2458.

Bizzarri, A. and Cocco, M. A., 2006, A thermal pressurization model for the spontaneous dynamic rupture propagation on a three-dimensional fault: 1. Methodological approach. Jour. Geophys. Res. 111, B05303, doi:10.1029/2005JB 003862.

Day, S. M., Dalguer, L. A., Lapusta, N. and Liu, Y., 2005, Comparison of finite difference and boundary integral solutions to three-dimensional spontaneous rupture. Jour. Geophys. Res. 110, B12307, doi:10.1029/2005JB003813.

Delouis, B., Nocquet, J. M. and Vallée, M., 2010, Slip distribution of the February 27, 2010 Mw $=8.8$ Maule Earthquake, central Chile, from static and high-rate GPS, InSAR, and broadband teleseismic data. Geophys. Res. Lett., 37, L17305, doi:10.1029/2010GL043899.

Engdahl, E. R. and Scholz, C. H., 1977, A double Benioff zone beneath the central Aleutians: an unbending of the lithosphere. Geophys. Res. Lett., 4, 473-476.

Faulkner, D. R., Mitchell, T. M., Behnsen, J., Hirose, T. and Shimamoto, T., 2011, Stuck in the mud? Earthquake nucleation and propagation through accretionary forearcs. Geophys. Res. Lett., 38, L18303, doi:10.1029/2011GL048552.

Fujii, Y., Satake, K., Sakai, S., Shinohara, M. and Kanazawa, T., 2011, Tsunami source of the 2011 off the Pacific coast of Tohoku Earthquake. Earth Planets Space, 63, 815-820.

深畑幸俊 (Fukahata, Y.), 2009, 地震学における ABIC を用いたイ ンバージョン解析研究の進展. 地震 2 (Jour. Seismol. Soc. Japan, 2nd Ser.), 61, S103-S113.

Fukahata, Y. and Matsu'ura, M., 2005, General expressions for internal deformation fields due to a dislocation source in a multilayered elastic half-space. Geophys. Jour. Int., 161, 507-521.

Fukahata, Y. and Wright, T. J., 2008, A non-linear geodetic data inversion using ABIC for slip distribution on a fault with an unknown dip angle. Geophys. Jour. Int., 173, 353-364.

Fukahata, Y., Yagi, Y. and Miyazaki, S., 2011, Constraints on early stage rupture process of the 2011 Tohoku-oki earthquake from $1 \mathrm{~Hz}$ GPS data. Earth Planets Space, submitted.

Furukawa, Y. and Uyeda, S., 1989, Thermal state under the Tohoko arc with consideration of crustal heat generation. Tectonophysics, 164, 175-187.

Geller, R. J., 1976, Scaling relations for earthquake source parameters and magnitudes. Bull. Seismol. Soc. Amer., 66, 
$1501-1523$.

Hasegawa, A., Umino, N. and Takagi, A., 1978, Double-planed structure of the deep seismic zone in the northeastern Japan arc. Tectonophysics, 47, 43-58.

Hasegawa, A., Yoshida, K. and Okada, T., 2011, Nearly complete stress drop in the $2011 \mathrm{Mw} 9.0$ off the Pacific coast of Tohoku Earthquake. Earth Planets Space, 63, 703-707.

Hayes, G. P., 2011, Rapid Source Characterization of the 03-11$2011 \mathrm{Mw} 9.0$ Off the Pacific Coast of Tohoku Earthquake. Earth Planets Space, 63, 529-534.

日野亮太 - 鈴木健介・伊藤喜宏・金田義行 (Hino, R., Suzuki, K., Ito, Y. and Kaneda, Y.), 2011, 東北地方太平洋沖地震の前震 · 本震・余震の分布, 科学 (Kagaku) , 81, 1036-1043.

Honda, R., Yukutake, Y., Ito, H., Harada, M., Aketagawa, T., Yoshida, A., Sakai, S., Nakagawa, S., Hirata, N., Obara, K. and Kimura, H., 2011, A complex rupture image of the giant earthquake which struck east Japan revealed by a dense seismograph network, MeSO-net. Earth Planets Space, 63, 583-588.

Hori, T. and Miyazaki, S., 2011, A possible mechanism of $M 9$ earthquake generation cycles in the area of repeating $M 7 \sim$ 8 earthquakes surrounded by aseismic sliding. Earth Planets Space, 63, 773-777.

Ide, S., Baltay, A. and Beroza, G. C., 2011, Shallow Dynamic Overshoot and Energetic Deep Rupture in the $2011 \mathrm{Mw} 9.0$ Tohoku-Oki Earthquake. Science, doi:10.1126/science. 1207020.

池田安隆 - 岡田真介(Ikeda, Y. and Okada, S.), 2011, 長期的歪夕 蓄積過程と超巨大地震. 科学 (Kagaku), 81, 1071-1076.

Kanamori, H., 1971, Focal mechanism of the Tokachi-Oki earthquake of may 16, 1968: Contortion of the lithosphere at a junction of two trenches, Tectonophysics. 12,1-13.

Kanamori, H. and Anderson, D. L., 1975, Theoretical basis of some empirical relations in seismology. Bull. Seismol. Soc. Amer., 65, 1073-1095.

Kikuchi, M. and Kanamori, H., 1991, Inversion of complex body wave-III. Bull. Seismol. Soc. Amer., 81, 2335-2350.

古賀祥子 - 伊藤喜宏 - 日野亮太 - 篠原雅尚 - 海野德仁 (Koga, S., Ito, Y., Hino, R., Shinohara, M. and Umino, N), 2012, 日本海溝 周辺における太平洋プレート内の地震発生機構, 地震 2 (Jour. Seismol. Soc. Japan, 2nd Ser.), 64, 75-90.

Koketsu, K., Yokota, Y., Nishimura, N., Yagi, Y., Miyazaki, S., Satake, K., Fujii, Y., Miyake, H., Sakai, S., Yamanaka, Y. and Okada, T., 2011, A unified source model for the 2011 Tohoku earthquake. Earth Planet. Sci. Lett., 310, 480-487.

Lange, D., Tilmann, F., Barrientos, S. E., Contreras-Reyes, E., Methe, P., Moreno, M., Heit, B., Agurto, H., Bernard, P., Vilotte, J. P. and Beck, S., 2012, Aftershock seismicity of the 27 February $2010 \mathrm{Mw} 8.8$ Maule earthquake rupture zone. Earth Planet. Sci. Lett., 317, 318, 413-425.

Lay, T., Ammon, C. J., Kanamori, H., Xue, L. and Kim, M. J., 2011, Possible large near-trench slip during the great 2011 Tohoku (Mw 9.0) earthquake. Earth Planets Space, 63, 687692

Lee, S. J., Huang, B. S., Ando, M., Chiu, H. C. and Wang, J. H., 2011, Evidence of large scale repeating slip during the 2011 Tohoku-Oki earthquake. Geophys. Res. Lett., 38, L19306, doi:10.1029/2011GL049580.

McKenzie, D. and Brune, J. N., 1972, Melting on fault planes during large earthquakes. Geophys. Jour. Roy. Astr. Soc., 29, 65-78.

Magee, M. E. and Zoback, M. D., 1993, Evidence for a weak interplate thrust fault along the northern Japan subduction zone and implications for the mechanics of thrust faulting and fluid expulsion. Geology, 21, 809-812.

町田 洋 (Machida, H.), 2006, 第 4 章中部山岳(日本アルプス).4-3 飛騨山脈の地形, 町田洋・松田時彦・海津正倫・小泉武英編, 日 本の地形 5 中部(Regional Geomorphology of the Japanese
Islands, vol. 5 Geomorphology of Chubu Region), 東京大学 出版会 (Univ. Tokyo Press), 169-177.

松浦充宏 (Matsu'ura, M.), 1996, 変形と破壊. 地球惑星科学 6: 地 球連続体力学 (Earth and Planetary Science 6: Earth's Continuum Mechanics), 岩波書店(Iwanami Shoten), 175-237.

Mitsui, Y. and Hirahara, K., 2009. Coseismic thermal pressurization can notably prolong earthquake recurrence intervals on weak rate and state friction faults: Numerical experiments using different constitutive equations. Jour. Geophys. Res. 114, B09304, doi:10.1029/2008JB006220.

Mitsui, Y., Kato, N., Fukahata, Y. and Hirahara, K., 2012, Megaquake cycle at the Tohoku subduction zone with thermal fluid pressurization near the surface. Earth Planet. Sci. Lett., 325-326, 21-26.

Mitsui, Y., Iio, Y. and Fukahata, Y., 2011, A scenario for the generation process of the 2011 Tohoku earthquake based on dynamic rupture simulation: role of stress concentration and thermal fluid pressurization. Earth Planets Space, submitted.

Miura, S., Takahashi, N., Nakanishi, A., Tsuru, T., Kodaira, S. and Kaneda Y., 2005, Structural characteristics off Miyagi forearc region, the Japan trench seismogenic zone, deduced from a wide-angle reflection and refraction study. Tectonophysics, 407, 165-188.

Miyazaki, S., McGuire, J. F. and Segall, P., 2011, Seismic and aseismic fault slip before and during the 2011 off the Pacific coast of Tohoku Earthquake. Earth Planets Space, 63, 637642 .

小沢慎三郎 (Ozawa, S.), 2011. 余効変動. 科学 (Kagaku), 81, 1071-1076.

Rice, J. R., 2006, Heating and weakening of faults during earthquake slip. Jour. Geophy. Res., 111, B05311, doi:10.1029/ 2005 JB004006.

Sato, M., Ishikawa, T., Ujihara, N., Yoshida, S., Fujita, M., Mochizuki, M. and Asada, A., 2011, Displacement Above the Hypocenter of the 2011 Tohoku-Oki Earthquake. Science, doi:10.1126/science.1207401

Sawai, Y., Kamataki, T., Shishikura, M., Nasu, H., Okamura, Y., Satake, K., Thomson, K. H., Matsumoto, D., Fujii, Y., Komatsubara, J. and Aunget, T. T., 2009, Aperiodic recurrence of geologically recorded tsunamis during the past 5500 years in eastern Hokkaido, Japan. Jour. Geophys. Res., 114, B01319, doi:10.1029/2007JB005503.

Scholz, C. H., 2000, Evidence for a strong San Andreas fault. Geology, 28, 163-166.

Seno, T., 2009, Determination of the pore fluid pressure ratio at seismogenic megathrusts in subduction zones: Implications for strength of asperities and Andean-type mountain building. Jour. Geophys. Res., 114, B05405, doi:10.1029/2008 JB005889.

瀬野徹三, 2012, 南海トラフ巨大地震—その破壊の様態とシリーズに ついての新たな考えー 地震 2 (Jour. Seismol. Soc. Japan, 2nd Ser.) , 64, 97-116.

Shao, G., Li, X., Ji, C. and Maeda, T., 2011, Focal mechanism and slip history of $2011 \mathrm{Mw} 9.1$ off the Pacific coast of Tohoku Earthquake, constrained with teleseismic body and surface waves. Earth Planets Space, 63, 559-564.

Shibazaki B., Matsuzawa, T., Tsutsumi, A., Ujiie, K., Hasegawa, A. and Ito, Y., 2011, 3D modeling of the cycle of a great Tohoku-oki earthquake, considering frictional behavior at low to high slip velocities. Geophys. Res. Lett., 38, L21305, doi:10.1029/2011GL049308.

宾倉正展・澤井祐紀・行谷佑一・岡村行信 (Shishikura, M., Sawai, Y., Namegaya, Y. and Okamura, Y.), 2010, 平安の人々が見た 巨大津波を再現する一西暦 869 年貞観津波-, AFERC NEWS, 16, 1-10.

Sibson, R. H., 1973, Interactions between temperature and fluid pressure during earthquake faulting-a mechanism for partial 
or total stress relief. Nature, 243, 66-68.

Suzuki, W., Aoi, S., Sekiguchi, H. and Kumagai, T., 2011, Rupture process of the 2011 Tohoku-Oki mega-thrust earthquake (M9.0) inverted from strong-motion data. Geophys. Res. Lett., 38, L00G16, doi:10.1029/2011GL049136.

Terakawa, T. and Matsu' ura, M., 2010, The 3-D tectonic stress fields in and around Japan inverted from centroid moment tensor data of seismic events. Tectonics, 29, TC6008, doi:10.1029/2009TC002626.

東北大学大学院理学研究科(Tohoku Univ.), 2011, 第 193 回地震予 知連絡会資料 (Rep. Coordinating Committee Earthquake Prediction 193rd meeting).

Tsutsumi, A. and Shimamoto, T., 1997, High-velocity frictional properties of gabbro. Geophys. Res. Lett., 24, 699-702.

Umino, N., Kono, T., Okada, T., Nakajima, J., Matsuzawa, T., Uchida, N., Hasegawa, A., Tamura, Y. and Aoki, G., 2006, Revisiting the three M 7 Miyagi-oki earthquakes in the 1930s: possible seismogenic slip on asperities that were reruptured during the $1978 \mathrm{M}=7.4$ Miyagi-oki earthquake. Earth Planets Space, 58, 1587-1592.

Vallée, M. and Bouchon, M., 2004, Imaging coseismic rupture in far field by slip patches. Geophys. Jour. Intern., 156, 615-630.

Yabuki, T. and Matsu ura, M., 1992, Geodetic data inversion using a Bayesian information criterion for spatial distribution of fault slip. Geophys. Jour. Intern., 109, 363-375.

Yagi, Y. and Fukahata, Y., 2008, Importance of covariance com- ponents in inversion analyses of densely sampled observed data: an application to waveform data inversion for seismic source processes. Geophys. Jour. Intern, 175, 215-221.

Yagi, Y. and Fukahata, Y., 2011a, Rupture process of the 2011 Tohoku-oki earthquake and absolute elastic strain release. Geophys. Res. Lett., 38, L19307, doi:10.1029/2011GL 048701.

Yagi, Y. and Fukahata, Y., 2011b, Introduction of uncertainty of Green's function into waveform inversion for seismic source processes. Geophys. Jour. Intern. 186, 711-720.

Yamaguchi, A., Cox, S. F., Kimura, G. and Okamoto, S., 2011, Dynamic changes in fluid redox state associated with episodic fault rupture along a megasplay fault in a subduction zone. Earth Planet. Sci. Lett., 302, 369-377.

Yoshida, K., Miyakoshi, K. and Irikura, K., 2011, Source process of the 2011 off the Pacific coast of Tohoku Earthquake inferred from waveform inversion with long-period strongmotion records. Earth Planets Space, 63, 577-582.

Yoshida, Y., Ueno, H., Muto, D. and Aoki, S., 2011, Source process of the 2011 Off the Pacific Coast of Tohoku earthquake with the combination of teleseismic and strong motion data. Earth Planets Space, 63, 565-569.

Yue, H. and Lay, T., 2011, Inversion of high-rate (1 sps) GPS data for rupture process of the 11 March 2011 Tohoku earthquake (Mw 9.1). Geophys. Res. Lett., 38, L00G09, doi:10.1029/2011GL048700.

（要 旨）

深畑幸俊·八木勇治·三井雄太，2012，2011 年東北地方太平洋沖地震による絶対歪みの解放： 遠地実体波インバージョン解析と動的摩擦弱化. 地質雑, 118, 396-409. (Fukahata, Y., Yagi, Y. and Mitsui, Y., 2012, Absolute strain release in the 2011 Tohoku-oki Earthquake: Waveform inversion and dynamic fault weakening. Jour. Geol. Soc. Japan, 118, 396-409.)

2011 年東北地方太平洋沖地震では，海溝寄りの非常に大きな滑りに加え，宮城〜茨城県 沖の陸側に近い領域でも比較的大きな滑りがあったと考えられる. 特に, 地震開始後 20-35 秒くらいには, 1978 年宮城県沖地震の震源域付近で顕著なモーメント解放を生じた. 地震の主破壊は，長大な滑り(最大 $50 \mathrm{~m}$ ), 長い滑り時間 (最大 90 秒), 比較的大きな応力 降下 (約 $10 \mathrm{MPa}$ ) で特徵付けられ, thermal pressurizationなどの効果により断層面の摩擦 強度が極端に低下したことが強く示唆される．余震のメカニズム解が地震前と大きく変化 したことも，沈み込むプレート境界面でほぼ全ての歪みが解放されたことを意味し，摩擦 強度の極端な低下を裏付ける. 地震前の絶対応力レベルは, 震源付近から海溝にかけて約 $10 \mathrm{MPa}$ と推定された. 大地震時の破壊伝播は, thermal pressurization など非線形性の強 い効果に支配されていると考えられ, 海溝型大地震の擬周期的発生と調和的である. 